\title{
Ontogeny in marine tagging and tracking science: technologies and data gaps
}

\author{
Elliott L. Hazen ${ }^{1,2, *}$, Sara M. Maxwell ${ }^{3}$, Helen Bailey ${ }^{4}$, Steven J. Bograd ${ }^{2}$, \\ Mark Hamann ${ }^{5}$, Philippe Gaspar ${ }^{6}$, Brendan J. Godley ${ }^{7}$, George L. Shillinger ${ }^{8,9}$ \\ ${ }^{1}$ University of Hawaii Joint Institute for Marine and Atmospheric Research, Honolulu, Hawaii 96822, USA \\ ${ }^{2}$ NOAA Southwest Fisheries Science Center, Environmental Research Division, Pacific Grove, California 93950, USA \\ ${ }^{3}$ Marine Conservation Institute, Bellevue, Washington 98004, USA \\ ${ }^{4}$ Chesapeake Biological Laboratory, University of Maryland Center for Environmental Science Solomons, Maryland 20688, USA \\ ${ }^{5}$ School of Earth and Environmental Sciences, James Cook University, Townsville, Queensland 4811, Australia \\ ${ }^{6}$ Collecte Localisation Satellites, Parc Technologique du Canal, 31520 Ramonville Saint-Agne, France \\ ${ }^{7}$ Department of Biosciences, University of Exeter, Penryn, Cornwall TR10 9EZ, UK \\ ${ }^{8}$ Tag-A-Giant Fund - The Ocean Foundation, PO Box 52074, Pacific Grove, California 93950, USA \\ ${ }^{9}$ Center for Ocean Solutions, Stanford University, 99 Pacific Street, Suite 155A, Monterey, California 93940, USA
}

\begin{abstract}
The field of marine tagging and tracking has grown rapidly in recent years as tag sizes have decreased and the diversity of sensors has increased. Tag data provide a unique view on individual movement patterns, at different scales than shipboard surveys, and have been used to discover new habitat areas, characterize oceanographic features, and delineate stock structures, among other purposes. Due to the necessity for small tag-to-body size ratio, tags have largely been deployed on adult animals, resulting in a relative paucity of data on earlier life history stages. In this study, we reviewed tagging efforts on multiple life history stages for seabirds, marine mammals, marine turtles, and fish and enumerated studies focusing on each guild that targeted larvae, juveniles or hatchlings. We found that turtles and fish had higher proportion of studies focusing on juveniles $(>20 \%)$ than seabirds and marine mammals $(<10 \%)$. On both juveniles and adults, tags were used in a targeted manner with passive and transmitting tags as the main tools for population demography and connectivity studies, while GPS and archival tags were used more frequently for habitat analyses and foraging ecology. These findings identify the need to focus on novel approaches in tagging multiple life history stages both to study marine predator ecology and to effectively manage marine populations.
\end{abstract}

KEY WORDS: Tagging $\cdot$ Tracking $\cdot$ Biologging $\cdot$ Ontogeny $\cdot$ Juvenile $\cdot$ Top predator

\section{INTRODUCTION}

Tagging animals to obtain data on their movements and physiology has resulted in an unprecedented understanding of the distribution and behavior of marine animals (Rutz \& Hays 2009, Bograd et al. 2010). However, there are still large gaps in tagging science that need to be addressed (Godley et al. 2007, Hart \& Hyrenbach 2009). Though we are rapidly ad- vancing our capacity to close these gaps, important challenges remain; arguably the main limiting factor in furthering our ecological knowledge is the difficulty of advancing tag technology and size concurrently. In this review, we examine gaps in top predator tagging studies by determining the distribution of studies across life history stages, how gaps vary across predator taxonomic groups, and assess which gaps are the most important to fill. 
Tagging of marine animals has developed into an innovative discipline, currently using physical or chemical tracers to mark individuals and technologically advanced data loggers to understand how animals interact with their environment. Early efforts for marine species featured spaghetti tags implanted in fish muscle (e.g. Everhart et al. 1975, Bayliff 1988, Pollock 1991), body markings such as fin/scute clippings or number branding (e.g. L. Gaustella \& G. Hughes unpubl.), and metal bands attached to a leg or flipper (Limpus 1992). These simple tags supported the first mark and recapture studies identifying movements and home ranges of many taxonomic groups, and eventually allowed measurements of demographic parameters such as growth rates and age of maturity (e.g. Bjorndal et al. 2000, Sibert \& Nielsen 2001, Limpus \& Limpus 2003). As electronics became miniaturized, more complex tags were developed and a greater range of species was tagged. The genesis and early history of electronic tagging techniques is summarized in Naito (2004) and Kooyman (2004). Acoustic transmitters, for example, allow for automated resightings of tagged animals to provide a more temporally complete snapshot for mark-recapture analyses (Sibert \& Nielsen 2001). More recently, archival and satellite tags often measure light and temperature, and many broadcast an animal's location either upon surfacing, or after tag release and data transmission from the surface. These advances have resulted in a number of broad-reaching findings about animal behavior and distribution (Weimerskirch et al. 2000, Shillinger et al. 2008, Block et al. 2011). However, significant data gaps remain, particularly with respect to smaller organisms and early life history stages (Fedak et al. 2002).

Ship-based survey data, nesting beach, rookery or colony counts, and fisheries catch data are among the traditional methods for measuring marine top predator behavior, distribution, and/or abundance in the field. Survey data provide a Eulerian snapshot of multiple animals sighted at the sea surface (e.g. marine mammals or seabirds), caught by hook or net, or on land (nesting beaches and rookeries). Ship based surveys allow for instantaneous measurements of behavioral state and estimates of abundance, but 'sightability' varies depending on factors such as species, behavior, and weather conditions (e.g. Pollock et al. 2004). Tracking of an individual or group of animals, measuring social and behavioral cues at a fixed interval, can provide more complete behavioral measurements during surveys (e.g. Hodgson \& Marsh 2007). Fisheries catch data are similar to survey data in providing a snapshot of distribution, but there is a function of catchability, similar to sightability, as animals have to be both present and unable to avoid hooks or nets. However, for some species, such as the flatback turtle, much of what is known about their non-nesting distribution comes from fisheries catch data (Dryden et al. 2008).

In contrast to the Eulerian approaches, tag data can measure Lagrangian movement of a tagged individual, offering finer scale and longer continuous time series while potentially collecting behavior below the ocean surface. As sighting-based data alone can rarely assess ontogeny, tag data are required to understand how multiple life stages interact with the environment. For juvenile oceanic top predators, some of the key ecological questions that require investigation include (1) population structure and recruit mortality, (2) critical juvenile habitat and overlap with threats, (3) dispersal and population connectivity, and (4) foraging ecology. With numerous deployments, the spatial and temporal resolution of tag data allow scientists to assess abundance using recapture metrics (e.g. Taylor et al. 2011), as well as understand how predators use pelagic environments both behaviorally (e.g. feeding, reproduction, migration corridors) and across temporal scales (daily, seasonally, or annually).

\section{TAGGING TECHNOLOGY}

The field of marking and tagging can be classified into 2 broad categories: passive and active. Marking applies or uses an existing visual or otherwise detectable tracer to an organism allowing resighting (e.g coloration, genetics, or chemical patterns). Passive tags can be non-electronic, 'conventional' forms of tagging (e.g. flipper or spaghetti) that have been employed for decades, or can reflect a signal when in contact with an electronic reader. As passive tags are not limited by battery life, they can last across multiple life-history stages if not shed. For example, salmon with passive tags implanted as smolts are measured 3+ yr later as adults when they swim upriver to spawn (e.g. Castro-Santos et al. 1996) and marine turtles tagged with flipper tags as juveniles are recaptured decades later as adults (Limpus \& Limpus 2001, Limpus et al. 2003). The simplest and cheapest tags can be deployed on multiple individuals at a fraction of the cost of more complex tags, but collect less information.

Conventional tags are implanted in muscle or attached to the animal with a unique identifier and 
require recapture to measure growth or to identify a start and end-point of movement patterns (White \& Beamish 1972, Balazs 1999). Passive integrative transponder (PIT) tags provide automatic identification of tagged individuals either through manual scanning by a researcher or via in situ automated receivers deployed at key locations, such that all individuals passing get scanned (e.g. Barbour \& Adams 2012, this Theme Section). These approaches do not require power and thus can last until shed by the tagged individual. Results from conventional or PIT tags are traditionally used to inform migration rates, mortality, and ontogenetic shifts in biological parameters.

Active tags include a broad suite of technologies and can be separated into 2 categories: transmitting and archival tags. Radio tags are commonly used in terrestrial studies as they transmit a radio signal through air for locating a tagged animal, but also have been used on regularly surfacing marine species (e.g. Whiting \& Miller 1998) and in combination with archival tags to assist retrieval (Johnson \& Tyack 2003, Weber et al. 2011). Acoustic tags use a specific frequency and transmitting pattern to identify individuals when they pass within detection range of an underwater hydrophone or receiver (Arnold \& Dewar 2001). This receiver may be in the form of a listening station such as a hydrophone, or in the form of another animal carrying a receiver. 'Chat' tags record the presence of other animals equipped with transponders, giving data on both the movement of animals in the vicinity of the receivers and inter-individual associations (Voegeli et al. 2001, Holland et al. 2009, Guttridge et al. 2010). Acoustic tags transmit frequently, are detectable up to a few kilometers from a receiver, and allow longer-range detectability than PIT tags. However, acoustic tag duration is limited by battery size, transmission frequency, and detectability.

Satellite tags are particularly useful for flying or air-breathing animals as position information is transmitted when the tag has an uninterrupted path to orbiting satellites upon surfacing. The Advanced Research and Global Observation Satellite (ARGOS) system both allows the positioning of the surfacing animal and can transmit a limited amount of information. As the Global Positioning System (GPS) has a higher accuracy than ARGOS ( $\mathrm{km}$ for ARGOS, $\mathrm{m}$ for GPS; Hazel 2009, Costa et al. 2010a) GPS receivers are often inserted in ARGOS tags. Alternatively, GPS data can be stored on-board for retrieval upon tag recovery for animals with regular surfacing bouts (Phalan et al. 2007, Cordes et al. 2011). Fastloc GPS receivers have revolutionized the potential for GPS technology use in marine animals, as they gather positioning data in less than a second and therefore allow positioning even during short surfacing events (Sims et al. 2009, Costa et al. 2010a, Witt et al. 2010a).

Archival tags actively record time-series data of multiple sensors, which are stored within the device and can be obtained by researchers upon recovery or, for tags with transmitting capabilities, on detachment (Block et al. 1998, Phillips et al. 2004, Schaefer et al. 2007, Weng et al. 2009). Archival tags originated as depth-loggers that recorded mean dive metrics on a coarse time scale (Arnold \& Dewar 2001), but current tags can record behavioral data at high frequency, including detailed dive behavior, energy expenditure, oceanographic data such as subsurface temperature and light levels, and/or location data. Recovery of archival tags occurs either by recapturing the animal and removing the tag with the full dataset, or via pop-up when archival tags detach from the animal at a pre-programmed time, reach the surface, and send summarized archived positions and sensor data to the satellite (Block et al. 1998, Block et al. 2001, Schaefer et al. 2007, Weng et al. 2009). Position data can be calculated from onboard light-sensors based on day lengths and sunrise/sunset times when animals enter the photic zone, also known as geolocation. With such a technique, location errors can exceed $1^{\circ}$ latitude and/or longitude (Block et al. 2001). Recent efforts to use additional data sources, such as sea surface temperature (SST) or the Earth's magnetic field, have improved lightbased geolocation estimates (Teo et al. 2004, Royer et al. 2005, Nielsen et al. 2006). Archival tag deployments can last from 1 to $3 \mathrm{yr}$, but longer-term life history transmitters are designed to collect internal vital rates over the life of an animal and transmitting upon mortality and tag release (Horning \& Hill 2005).

Short-term archival tags include suction cup tags that can collect high-frequency data over a short duration (e.g. $24 \mathrm{~h}$ ) and can include multiple sensors when tag size is less limiting (e.g. large baleen whales). This can include 3 -axis accelerometers to reconstruct underwater behavior (Johnson \& Tyack 2003, Ware et al. 2006, Shepard et al. 2008, Okuyama et al. 2009), stomach temperature sensors, and jaw based accelerometers or magnetic triggers to identify foraging events (e.g. Myers \& Hays 2006, Bestley et al. 2008, Hanuise et al. 2010). These have been miniaturized in the example of 'daily-diary' tags, which can be deployed on multiple species providing accelerometer data at extremely high temporal resolution (Wilson et al. 2008). Low-light cameras, which 
archive still or video images even in low-photic regions, can further improve our understanding of underwater movements, and calibrate behaviors to changes in acceleration data (Heithaus et al. 2001, Gómez Laich et al. 2009). Data visualization of tag data and videos from cameras are important tools for outreach efforts and public education in addition to their scientific merit.

Even though tags are undergoing rapid technological advances (e.g. more sensors, decreased size, and increased battery life), tag makers and researchers must decide on trade-offs across these categories. The choice of tag types has largely been made based on the ecological questions being studied (e.g. fine-scale foraging versus large-scale migration) but often animal size, funding limitations and ethical considerations may dictate the number of tags available, the tagging methodology used, and the ability to re-tag individuals or tag others in the future. As the largest individuals are usually the first to be studied using tagging, one of the biggest data gaps still remaining are the juvenile and subadult life stages, which are often the most critical periods for survival (e.g. Elliott 1989). Tag research and development has progressed to the point that tags are now small and light enough to be used on smaller individuals, and consequently younger life stages, although it is critical that any potential impacts are evaluated (Witt et al. 2011, Vandenabeele et al. 2012).

\section{TOP PREDATOR GROUPS AND TAGGING}

Life cycles across top predator taxonomic groups vary widely, and different life stages have contrasting behavioral modes and habitat requirements, resulting in a diversity of challenges in applying tagging techniques (Fig. 1, Tables 1 \& 2). Planktonic fish larvae settle in juvenile nursery habitat until they mature into adults, often encompassed by different habitat characteristics and constraints (Balon 1986, Beck et al. 2001). Seabirds and marine mammals have precocial stages during which they are dependent on their parents. For birds and pinnipeds, this stage lasts until they leave the nest or colony and begin their own foraging trips as juveniles, and for cetaceans until they are weaned. Upon maturation, pinnipeds and seabirds undergo yearly or multi-year cycles of molting, breeding, egg-laying or birthing, followed by post-breeding trips that have very different energetic requirements and migration strategies, requiring multi-stage tagging efforts (Kappes et al. 2010). Cetaceans and sirenians have slightly different constraints because they do not have the same ties to land as seabirds and pinnipeds, but some cetaceans breed at low latitudes and undergo long-distance migrations between their foraging

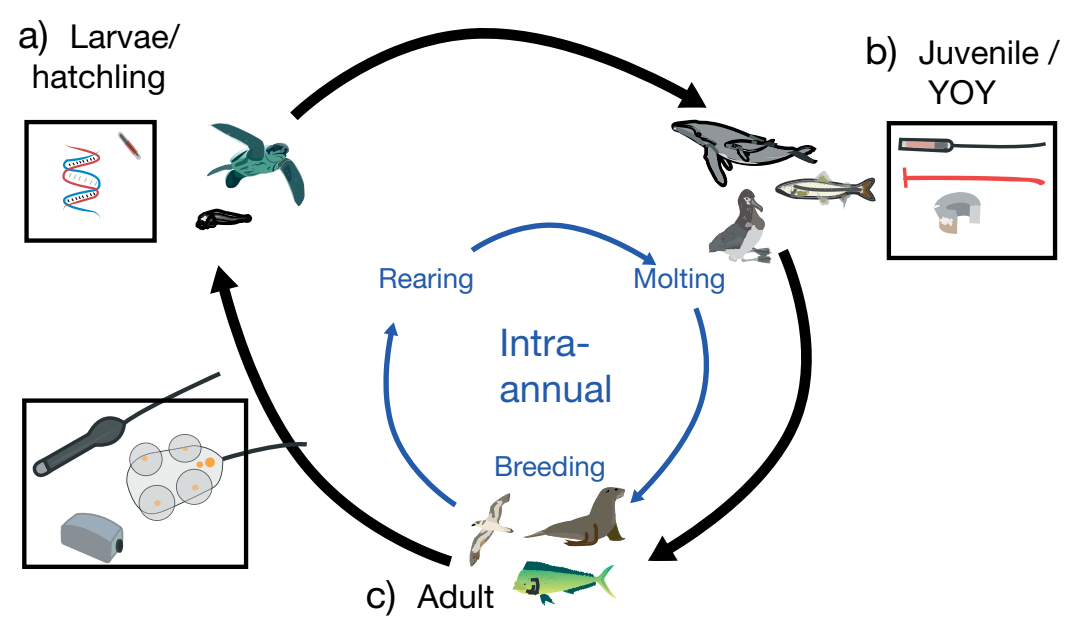

Fig. 1. Simplified representation of life history stages and tags commonly used at that stage for predator taxonomic groups (outer circle). The inner circle (blue) is a reminder of intra-annual stages in adults that can result in different constraints, tag retention rates, and behavioral patterns. (a) Larvae/hatchlings include seabird chicks, sea turtle hatchlings, marine mammal pups and calves, and fish larvae, all of which pose difficulties in tag attachment. Both sea turtles and fish are very small and have very high mortality, making adequate tagging a costly exercise. Three common marking mechanisms include markings (fin clipping), implantable passive integrated transponder (PIT) tags, requiring a reader to get the unique identifier, and isotopic or genetic markers to address habitat and population connectivity questions. Marine mammal and seabird offspring are often tied to their parents (or to land), allowing behavioral inference from their parents or from land. (c) Juveniles and young-of-the-year (YOY) are not yet reproductively active and are focused on minimizing predation risk while maximizing foraging to amass body weight, which may result in different habitat requirements or migration pathways than those of adults. In addition to PIT tags, spaghetti tags in fish, and flipper tags and banding in pinnipeds, turtles, and seabirds can be used for simple mark-recapture data. For larger fish, acoustic tags can be used to identify residence rates and migration behavior across acoustic receivers. (c) Adults can hold the largest tags and have traditionally been the most sampled for this reason. Tags used include GPS positioning tags in birds and mammals, longterm pop-up archival tags for coarse positioning and temperature measurements in fish species, and fine-scale archival suction cup tags to measure underwater behavior of marine mammals 
Table 1. Total number of tagging studies and percentage focusing on juvenile life stages by guild from the literature search in Web of Science. The search terms included ('bird*' OR 'mammal*' OR 'fish*' OR 'turtle*' OR 'cetacean*' OR 'dolphin*' OR 'whale*' OR 'otter*' OR 'seal*' OR 'sea lion*') AND ('ocean*' OR 'marine*' OR 'sea*' OR 'pelagic *') AND ('satellite*' OR 'tag*' OR 'track *') AND ('PIT*' OR 'passive integrated transponder*' OR 'ARGOS*' OR 'GPS*' OR 'popup*' OR 'radio*' OR 'acoustic *' OR 'archival*') with early life stages including ('juvenile*' OR 'sub-adult*' OR 'subadult*' OR 'fledging*' OR 'hatchling*' OR 'YOY*' OR 'yearling*' OR 'Young of the year*' OR 'fry*' OR 'smolt*' OR 'larvae*')

\begin{tabular}{|lcccc|}
\hline & $\begin{array}{c}\text { Marine } \\
\text { mammal }\end{array}$ & Fish & Turtle & Seabird \\
\hline All & 735 & 2318 & 291 & 603 \\
Juvenile (\%) & 6.0 & 23.9 & 26.5 & 8.8 \\
\hline
\end{tabular}

and calving grounds (Corkeron \& Connor 1999, Rasmussen et al. 2007). Sea turtles arguably have the least understood juvenile stages (Reich et al. 2007). Sea turtle tracking research has focused on nesting females due to accessibility on the nesting beaches (Godley et al. 2007). Hatchling sea turtles have high mortality rates (Santidrián Tomillo et al. 2010), and are not seen again for extended periods (of more than a decade) until they are reproductively active, when only females return to the nesting beaches (Carr 1967, Shillinger et al. 2012).

\section{Fishes}

Fishes have had the longest tagging history, given the commercial importance of many species and, in general, less stringent permitting requirements compared to other taxa. Tagging studies have been able to shed light on key ecological processes such as population structure and connectivity (Taylor et al. 2011), movement patterns (Bonfil 2005), and marine hotspots (Block et al. 2011). Of the 4 taxonomic groups considered, relatively greater effort has been devoted to understanding multiple life stages of fish ( $24.7 \%$ of studies were on juveniles), in part because habitat requirements can vary through ontogeny (Table 1). Larval fish are very small $(<\sim 5 \mathrm{~mm})$ and have extremely high mortality, due largely to starvation and predation (Houde 1997). This complicates efforts to track juvenile fish in sufficient numbers. The degree of larval dispersal and retention largely determines population connectivity in marine fish populations, and understanding these patterns is critical for management of essential fish habitat, understanding vulnerability to climate variability and threats, and the implementation of space-based management tools (Thorrold et al. 2002, Palumbi et al. 2003). For this reason, many of the studies to date have used modeling approaches to simulate patterns of dispersal (Cowen \& Sponaugle 2009), when tag deployments remain untenable due to cost and size

Table 2. Categories of research questions answered using tagging studies, organized by taxonomic group and ontogenetic stage. Each cell indicates the status of tag-based ecological research (many studies: $>10$; some: $>5$; few: $<3$ ), tag types that were commonly used to answer these questions, and reference to a review, seminal, or novel study where available. Tag types are: (1) visual and molecular techniques (e.g. Photo-ID, branding, genetics, isotope ratios); (2) passive tags (e.g. spaghetti, band, flipper, passive integrated transponder [PIT]); (3) active transmitting tags (e.g. radio, acoustic, chat-tags); (4) satellite tags (e.g. GPS, ARGOS, Fastloc GPS); (5) short-term archival tags (e.g. camera tags, accelerometer-based tags, magnetic sensor tags, internal temperature/heart rate); (6) long-term archival tags (e.g. pop-up archival, internal temperature/heart rate, life history tag, daily diary tag)

\begin{tabular}{|c|c|c|c|c|c|c|c|c|}
\hline & \multicolumn{2}{|c|}{ - Marine mammal —ـ } & \multirow[b]{2}{*}{ Adult } & \multirow{2}{*}{$\mathrm{h}$} & \multicolumn{2}{|c|}{ - Turtle } & \multicolumn{2}{|c|}{ - Seabird } \\
\hline & Adult & Juvenile & & & Adult & Juvenile & Adult & Juvenile \\
\hline $\begin{array}{l}\text { Mortality/ } \\
\text { population } \\
\text { size }\end{array}$ & $\begin{array}{c}\text { Many }(1,2) \\
\text { Hammond } \\
2002\end{array}$ & $\begin{array}{l}\text { Some }(1,2) \\
\text { Pistorius } \\
\text { et al. } 2000\end{array}$ & $\begin{array}{l}\text { Many }(1,2 \text {, } \\
\text { 3,5) Pine } \\
\text { et al. } 2003\end{array}$ & $\begin{array}{c}\text { Many }(1,2,3) \\
\text { Pine } \\
\text { et al. } 2003\end{array}$ & $\begin{array}{c}\text { Many }(1,2,3,4,5) \\
\text { Bradshaw } \\
2005\end{array}$ & $\begin{array}{c}\text { Some (2) } \\
\text { Chaloupka \& } \\
\text { Limpus } 2005\end{array}$ & $\begin{array}{c}\text { Many (2) } \\
\text { Weimerskirch } \\
\text { et al. } 1998\end{array}$ & Few (2) \\
\hline Connectivity & $\begin{array}{c}\text { Many }(1,2,4) \\
\text { Witteveen } \\
\text { et al. } 2009\end{array}$ & $\begin{array}{l}\text { Some }(1,2) \\
\text { Oosthuizen } \\
\text { et al. } 2011\end{array}$ & $\begin{array}{c}\text { Many }(1,2,3 \\
\text { 5) Thorrold } \\
\text { et al. } 2002\end{array}$ & $\begin{array}{c}\text { Many }(1,2) \\
\text { Thorrold } \\
\text { et al. } 2002\end{array}$ & $\begin{array}{c}\text { Many }(1,2,4) \\
\text { Bowen et al. } \\
1994\end{array}$ & $\begin{array}{c}\text { Some }(1,2) \\
\text { Godley et al. } \\
2010\end{array}$ & $\begin{array}{c}\text { Many }(1,2,3 \\
\text { 4,6) Friesen } \\
\text { et al. } 2007\end{array}$ & $\begin{array}{l}\text { Some }(1,3,4) \\
\text { Votier et al. } \\
2011\end{array}$ \\
\hline Habitat & $\begin{array}{c}\text { Many }(1,2,4 \\
\text { 5,6) Kenney } \\
\text { et al. } 2001\end{array}$ & $\begin{array}{c}\text { Some }(4,6) \\
\text { Burns } \\
1999\end{array}$ & $\begin{array}{c}\text { Many }(2,3,6) \\
\text { Block et al. } \\
2011\end{array}$ & $\begin{array}{l}\text { Many }(2,3) \\
\text { Gillanders } \\
\text { et al. } 2003\end{array}$ & $\begin{array}{l}\text { Many }(1,2,3, \\
4,6) \text { Bailey et } \\
\text { al. } 2012\end{array}$ & $\begin{array}{c}\text { Many }(1,3,4) \\
\text { Musick \& } \\
\text { Limpus } 1997\end{array}$ & $\begin{array}{l}\text { Many }(1,4 \\
5,6) \text { Wakefield } \\
\text { et al. } 2009\end{array}$ & $\begin{array}{c}\text { Some }(4,6) \\
\text { Kooyman \& } \\
\text { Ponganis } 2007\end{array}$ \\
\hline $\begin{array}{l}\text { Foraging } \\
\text { ecology }\end{array}$ & $\begin{array}{c}\text { Many }(1,5,6) \\
\text { Croll et al. } \\
1998\end{array}$ & $\begin{array}{c}\text { Some }(5,6) \\
\text { Tyson et al. } \\
2012\end{array}$ & $\begin{array}{c}\text { Many }(1,5,6) \\
\text { Cunjak et al. } \\
2005\end{array}$ & $\begin{array}{c}\text { Some }(3,5,6) \\
\text { Bestley et al. } \\
2008\end{array}$ & $\begin{array}{c}\text { Many }(1,2,3 \\
4,5,6) \text { Eckert } \\
\text { et al. } 1989\end{array}$ & Few $(1,3)$ & $\begin{array}{c}\text { Many }(1,3,4 \\
5,6) \text { Wakefield } \\
\text { et al. } 2009\end{array}$ & $\begin{array}{c}\text { Some }(4,6) \\
\text { Weimerskirch } \\
\text { et al. } 2006\end{array}$ \\
\hline
\end{tabular}


limitations. As an alternative, developmental tracers such as artificial (e.g. fluorescent or radioactive tracers) and natural isotopic markers have been used to measure connectivity, dispersal, and natal homing in the marine environment (Thorrold 2001, Palumbi et al. 2003). Using a combination of genetic and geochemical techniques, researchers have been able to inform understanding of habitat use and movement, providing critical knowledge for delineating stocks and managing migratory species (Thorrold et al. 2002, Cowen \& Sponaugle 2009).

Passive tags have been effective for tracking juvenile fish because of their small size and lower cost, which are important considerations due to the high mortality in this life stage (Kipling \& Lecren 1984). Passive markings (e.g. fin clips), spaghetti or coded wire tags, and PIT tags in hatchery fish have been valuable in informing our knowledge of juvenile salmon migration and survival (Castro-Santos et al. 1996). By measuring the proportion of tagged salmon returning to the mouth of a spawning river, scientists can calculate survival rates, which are essential for estimating stock size and setting fisheries catch limits. Unlike fin clippings or coded wire tags, PIT tags can be read by in-water readers without recapture, providing more information on both the onset of migration and the population level timing of migration, independently of sampling effort. These passive techniques are still critical for tagging many smaller fish species, and they have provided insight into the survival, recruitment, and population dynamics of young and adult fish (e.g. Barbour \& Adams 2012).

Active tags have been applied to juvenile and adult life history stages to provide measurements of core habitat and improved estimates of survival. Moreover, these tags can also provide information about emigration, when the individual may be lost to re-sampling techniques (Pine et al. 2003, Hammerschlag et al. 2011). Acoustic tags are useful for migration studies of juvenile and adult stages, particularly in areas where a high density of receiver arrays allows the calculation of percent occupancy and migration rates among receivers (Welch et al. 2002). Acoustic tags can also reveal fine-scale responses to estuarine or oceanic processes, e.g. avoidance of hypoxia (Brady et al. 2009) and effects of other environmental variables, e.g. exposure to solar ultraviolet-B radiation (Melnychuk at al. 2012, this Theme Section). Combined with measures of environmental characteristics such as prey distribution, key inferences can be made about foraging behavior and ecology of predatory fish such as tuna, relative to prey distributions (Josse et al. 1998). With the deployment of additional receiver arrays (includ- ing mobile tags that serve as arrays; Holland et al. 2009) and greater tagging effort, acoustic tags have potential for monitoring marine populations at multiple spatiotemporal scales, particularly to understand use patterns in critical or protected habitat. Acoustic tags remain a key tool in understanding fine-scale movement and behavior of fish by providing multiple recaptures at a broader scale than PIT tag readers and at lower cost than archival or satellite-based methods.

Larger tags, such as pop-up archival tags, are too large to be applied to most young fish life stages (though see Rowat et al. 2007), but they have provided valuable insights in the study of large predatory fishes and sharks. These fish have been outfitted with pop-up tags to assess movement patterns (Block et al. 2001, Humphries et al. 2010), behavioral ecology (Sims 2010, Hammerschlag et al. 2011), spawning habitat (Block et al. 2001), and more recently to improve stock assessment models (Taylor et al. 2011). One of the broadest syntheses of top predator behavior, habitat use, and migration patterns analyzed 7 fish species (of 23 total top predators) to describe seasonal patterns of migration, identify biodiversity hotspots, and quantify physical characteristics of these hotspots in the North Pacific (Block et al. 2011). Combining pop-up tags with stomach temperature loggers has allowed physiological detection of feeding events through the heat loss of a prey capture event followed by an increase in core body temperature after digestion (Clark et al. 2008). Trawl and longline data, and tag-based mark-recapture studies are the 3 primary tools used to assess fish species biomass, and the integration among data types (e.g. combining passive and active techniques; Cunjak et al. 2005) has improved our understanding of fisheries ecology. Given the large number of species of fish and their varied life-history and behavioral characteristics, smaller and cheaper tags could provide ecological knowledge of pelagic forage species to inform ecosystem studies (Cury et al. 2011), and better estimate fisheries-independent mortality rates for heavily fished species. While spatial management approaches are used to protect adult fish and even spawning aggregations, these efforts may be undermined by high mortality of juvenile life stages outside of protected areas, resulting in poor recruitment to the adult spawning stock (Hooker \& Gerber 2004).

\section{Sea turtles}

Sea turtle tagging efforts have used technology from flipper tagging and paint-based markers begin- 
ning in the 1930s to satellite tracking in the early 1990s (Godley et al. 2007). Despite difficulties, sea turtle researchers have tracked multiple life stages (27.0\% of studies explicitly included juvenile life stages; Table 1), though the research questions and methods vary depending on turtle size. For hatchlings, tethered tags have been used to investigate predation rates, dispersal patterns and behavior (e.g. Gyuris 1994, Salmon et al. 2010) and genetic markers have been applied to understand the fidelity displayed by sea turtles to their natal beaches later in life (Bowen et al. 1994). Although there remain logistical and financial challenges in tracking large enough sample sizes of hatchling turtles to answer ecological questions - such as those associated with post-hatching frenzied movements - it is becoming more feasible because acoustic transmitter tags are approaching suitable weights $(<1 \mathrm{~g})$.

Passive flipper tags and PIT tags have been used to track the survival, movements and nesting characteristics of turtles large enough to retain tags through time (e.g. Limpus et al. 2003, Chaloupka et al. 2008). While these marking techniques still remain a vital tool for sea turtle monitoring and conservation, the field of sea turtle tagging has grown exponentially as the availability of satellite and archival tags has increased and they have become more affordable. The increase has been particularly evident in the increase in studies using tracking tools to investigate migration pathways, albeit with generally low sample sizes (Godley et al. 2010). Satellite tracking produces data relatively quickly, in comparison to the possibly long waiting time required for recoveries from flipper tags. Moreover the publicly viewable data generated by satellite tracking often has concurrent educational and public awareness benefits for researchers interested in the human aspects of sea turtle conservation.

As many turtle species make ocean-basin scale migrations encompassing multiple years, study of their life history requires a broad-scale (temporal and spatial) approach (Godley et al. 2007). Studies have revealed cross-oceanic migrations by a number of species such as loggerheads and leatherbacks (Hughes et al. 1998, Shillinger et al. 2008, Benson et al. 2011, Witt et al. 2011), as well as fidelity to foraging grounds over the course of years (e.g. Limpus et al. 1992, Limpus \& Limpus 2001, Schofield et al. 2010, Shillinger et al. 2011), and fine-scale movements that can span national and international jurisdictions (Eckert 2002, Witt et al. 2008, Shillinger et al. 2010, Maxwell et al. 2011). The technology required to address research questions at a variety of spatial scales is increasingly available. However, the temporal scale is often constrained, particularly as sea turtles are long lived and some of the data gaps in the knowledge of younger life stages span several years (Hazel et al. 2009).

Because many turtles undertake long oceanic migrations, and traditional use of satellite telemetry addressed migration based questions, fine-scale studies using acoustic or radio tags have been less commonly used with sea turtles, although such approaches have been critical for identifying finescale foraging habitat and fisheries overlap (Taquet et al. 2006, Brooks et al. 2009, McClellan \& Read 2009) and allowing recaptures of individuals for behavioral and physiological studies (e.g. Wibbels et al. 1990, Witt et al. 2010b). Again, advances in automated acoustic telemetry systems and acoustic tags, coupled with larger-scale, multi-species investment in acoustic arrays (e.g. the Australian Animal Tagging and Monitoring System; imos.org.au/aatams. $\mathrm{html}$ ) address fine-scale habitat use by sub-adult and adult sea turtles.

Although the adult female bias is not as profound as in sea birds and marine mammals. satellite tags are rarely deployed on male or juvenile sea turtles (Godley et al. 2007), despite many juvenile age classes being large enough to carry equipment. This bias is likely due to a variety of reasons. Adult females are the demographic group most encountered as they emerge on land to nest; they are migratory and are highly important for the reproduction of the species. Moreover studies on sub-adult and/or adult male age classes generally require tags with higher accuracy, higher than traditional satellite tags could offer. In addition to the bias towards adult females, most of the studies to date investigate migration, while fewer studies address the behavior of inter-nesting turtles (Tucker et al. 1995, Zbinden et al. 2007, Tucker 2010). Identifying and remedying knowledge deficiencies is necessary in order to adequately protect populations at relevant spatial and temporal scales (Hays et al. 2001, Santidrián Tomillo et al. 2008, Hamann et al. 2010).

Sea turtle researchers have made advances in applying tracking data to understand population level movements and other management-relevant questions. For example, leatherback sea turtle researchers have conducted pan-oceanic syntheses, where multiple tagging datasets have been combined to understand movement patterns across populations in the Pacific Ocean (Bailey et al. 2012) and to investigate the efficacy of the global marine protected areas (MPA) system for green turtles (Scott et 
al. in press). Tracking data have been combined with genetic analyses and models of juvenile drift trajectories to unravel migratory connectivity in East Atlantic green turtles (Godley et al. 2010). Additionally, passive tags, biologging, and fisheries catch data have been combined to make a novel management tool, Turtlewatch, that predicts loggerhead turtle habitat in near real time to reduce interactions with fisheries (Howell et al. 2008). Novel uses and data integrations are critical for the adaptive management of these highly migratory and poorly understood species, and should become more feasible as synthetic data continue to be collected.

\section{Marine mammals}

Marine mammal studies are the least focused on multiple life stages, with only $6.0 \%$ of studies representing juvenile populations (Table 1). This is largely due to the logistical difficulties of tagging cetaceans and sirenians, obtaining permits, and developing tag designs with low enough drag to minimize its biological effect (Mate et al. 2007, McConnell et al. 2010). Passive tags and marking, however, have proven useful for all life history stages, particularly for pinnipeds. Their regular return to land provides a reliable location for resighting and recovery of tags. Branding and flipper tags have been used extensively (Bradshaw et al. 2000, McMahon et al. 2006) and have allowed estimates of age-specific survival (McMahon et al. 2003). The earliest passive tagging efforts on large cetaceans used numbered 'Discovery' tags deployed via harpoon that were eventually recovered during whaling harvest to reveal migration and population structure (see Mate et al. 2007). Since then, researchers have shifted to using unique markings on flukes, dorsal fins, and saddle coloration in photo-identification based mark-recapture studies (e.g. Wilson et al. 1999, Calambokidis et al. 2001) that identify individuals of multiple age classes (Jefferson et al. 1993). These photographs serve as the largest databases of individuals for many cetacean species. Although these passive tags have provided exceptional knowledge about population biology, including abundance estimates, social structure, reproductive success and long distance migrations, a detailed understanding of the movements of marine mammals cannot be gained from these techniques alone.

Active tagging has been used increasingly frequently for marine mammals since the 1980s and has provided a more detailed understanding of their movements across entire ocean basins (Mate et al.
2007). Ship and land based VHF tracking (Croll et al. 1998, Bjørge et al. 2002), and more recently shortterm archival tags (Johnson \& Tyack 2003), have been used in fine-scale behavioral studies, while satellite tags have provided broader-scale data on movement, distribution, and behavior of marine mammals (McConnell et al. 1999, Sheppard et al. 2006). At the finest scales, researchers have deduced individual foraging behavior using short-duration suction cup tags (Calambokidis et al. 2007, Hazen et al. 2009). Furthermore, suction cup tags with acoustic recorders have documented novel sound production in feeding whales that had not been previously detected (Stimpert et al. 2007). Due to their size, baleen whales have been outfitted with some of the largest tags and considerable improvements have been made since the earliest satellite tracking techniques (Mate et al. 2007). These approaches have revealed additional migratory routes and foraging habitat that cannot be detected by photo-identification techniques alone because animals often migrate through remote areas where there is little to no survey effort (Mate et al. 2007). Multi-sensor CTD data loggers measure conductivity, temperature and depth alongside a satellite-positioning transmitter (Hooker \& Boyd 2003). These sensors have allowed a more complete understanding of the animal's environment at a scale corresponding to the animal's behavior. Furthermore, these individual oceanobserving systems can serve as sentinels for environmental change by measuring physical oceanography and habitat use across multiple years (Boehme et al. 2008, Costa et al. 2010b).

Although there have been many tagging studies of marine mammals, they have mainly targeted adults. The greatest number of tagging studies on juvenile marine mammals has involved pinnipeds. Effort has also been particularly targeted towards northern Mirounga angustirostris and southern elephant seals M. leonina and Steller sea lions Eumetopias jubatus. Elephant seals are among the largest pinnipeds and the current tracking devices do not appear to adversely affect their performance in terms of mass gain or survival probability over short (seasonal) or long (multi-year) temporal scales (McMahon et al. 2008). Studies have tended to focus on survival rates, diving and foraging behavior. For example, timedepth recorders on northern elephant seals have revealed that the level of dive performance increases with age and experience up to $2 \mathrm{yr}$ of age, at which point their modal diving performance reaches that of an adult (Le Boeuf et al. 1996). The average depth, duration and frequency of dives made by Weddell 
seal Leptonychotes weddellii pups also increases rapidly in the period from birth to weaning, but slows soon thereafter, probably as a result of slower changes in mass and body composition (Burns 1999). Young seals tend to forage in shallower waters than adults and this is likely related to their diving ability (Campagna et al. 2007, Jeglinski et al. 2012). The foraging efficiency of younger seals is reduced relative to that of adults, owing to physiological and morphological constraints on aerobic dive duration, suggesting that low juvenile survival might result from behavioral constraints (Burns 1999).

Differences in the movements of juvenile pinnipeds have also been observed. Juvenile elephant seals migrate more slowly and less far than adults (Le Boeuf et al. 1996) - as has also been shown for Australian sea lions Neophoca cinerea (Fowler et al. 2007). In southern elephant seals, this results in significant differences in the total amount of the Southern Ocean covered by different age groups of the species (Field et al. 2005). On average younger seals make more trips to sea and do not travel as far on each trip. This leads to temporal and spatial segregation between animals of different ages, which would help to avoid intra-specific competition for resources on land, space on beaches, and at-sea foraging areas (Field et al. 2005). Spatial segregation in foraging areas between adults and juveniles has similarly been found in New Zealand fur seals Arctocephalus forsteri (Page et al. 2006). This is in contrast to studies on harbor seal Phoca vitulina and grey seal Halichoerus grypus movements that indicated that juveniles have larger home ranges and higher foraging effort than adults, which may suggest learning through experience (Lowry et al. 2000, Breed et al. 2011).

Steller sea lions are declining in numbers in most of Alaska and Russia (Loughlin et al. 2003), and reduced juvenile survival is believed to be a major contributing factor (Trites \& Donnelly 2003, RaumSuryan et al. 2004). Understanding the ontogenetic relationship between juvenile Steller sea lions and their foraging habitat is key to understanding their relationship to available prey and ultimately their survival. Loughlin et al. (2003) equipped young-ofthe-year (YOY) and yearling Steller sea lions with satellite-linked time-depth recorders. The yearling sea lion movement patterns and dive characteristics suggested that immature Steller sea lions are capable of making the same types of movements as adults. Long-range trips ( $>15 \mathrm{~km}$ and $>20 \mathrm{~h}$ ) start at around 9 mo of age and occur most frequently around the assumed time of weaning. Trip distance and duration increase with age (Loughlin et al. 2003, RaumSuryan et al. 2004). Horning \& Mellish (2012) determined post-weaning juvenile survival and causes of mortality using data received post-mortem via satellite from implanted archival life history transmitters. These showed there is high post-weaning mortality by predation in the eastern Gulf of Alaska region, which may be the largest impediment to recovery in this area (Horning \& Mellish 2012).

Very few tagging studies have been performed on juvenile cetaceans or sirenians. The small size of juvenile dolphins and porpoises increases the likelihood of biological impacts from tagging and the issue of hydrodynamic drag is a strong concern as attachment is usually on the dorsal fin. The small amount of work that has been done has mainly involved large whales, and in many cases it is the mother that has been tagged and inferences are then made about the movements of an accompanying calf. Resightings of tagged females with calves demonstrate that there is no apparent effect on the close association between mother and calf (Mate et al. 1997). For example, locations from satellite tagged southern right whale Eubalaena australis females with calves were grouped in specific areas along the coastline and corresponded to known concentration areas for mothercalf pairs. Tags on mother-calf pairs have a shorter tag life than in other classes, probably as a result of tag damage arising from the strong thigmotactic behavior shown by neonatal right whales towards their mothers (Best et al. 1993).

Studies on juvenile whales are less common due to permitting and tagging restrictions. Recent tags on both mother and calf humpback whales Megaptera novaeangliae have revealed new interactions including frequent synchronous foraging behavior (Tyson et al. 2012, this Theme Section). Belugas Delphinapterus leucas tagged as pairs of adults and young also showed correlations of dive behavior (Kingsley et al. 2001). A tagged humpback whale calf exhibited a higher surfacing rate than the adult whales (Lagerquist et al. 2008). It also showed a diel pattern with higher surfacing rates at night than during the day, which indicates it was nursing more at night. Satellite tagged juvenile and subadult $(\leq 13 \mathrm{~m})$ bowhead whales Balaena mysticetus in the Canadian Beaufort Sea mainly occurred over shallow water, and although they were tagged within a single week at one site they did not move in unison (Mate et al. 2000).

Tethered VHF and satellite tags have been used to provide knowledge to minimize the impacts of fishing bycatch, boat strikes and habitat loss on sirenians (Marsh et al. 2011). Satellite tracks of dugong Du- 
gong dugon movements have provided the first evidence that all age-sex classes perform large-scale movements, including mothers with calves. Differences in movement rates of manatees Trichechus manatus latirostris were detected between the sexes, with significantly faster rates for males than for females with or without calves (Flamm et al. 2005). Very little is known about the spatial ecology and behavior of sirenians and this is an important area for future research. Tagging techniques can allow information to be obtained in remote areas and higherresolution location data, such as GPS data, provide fine-scale information for examining risks and interactions with human activities.

Less invasive and short-duration archival tags (e.g. Johnson \& Tyack 2003, Andrews et al. 2008) may be preferable to larger, longer-term tags. A recent review on the effects of marking and tagging techniques on marine mammals highlighted that few studies have investigated the effects of markers on reproduction or growth (Walker et al. 2012). This will continue to be an important issue to address if tags are to be applied more frequently to juveniles in the future.

\section{Seabirds}

Similar to passive tagging efforts with terrestrial birds, seabird tagging began using leg and flipper bands for mark-recapture studies, followed by radio telemetry studies (Hart \& Hyrenbach 2009). These approaches have been used for adults and juveniles and have resulted in extensive understanding regarding population metrics, breeding ecology and to a lesser extent, the movements of birds whose tags have been resighted at sea (Ainley et al. 1994, Weimerskirch et al. 1997, Bonter \& Bridge 2011). PIT tags have had limited use in seabirds, though they have been used to answer questions related to breeding ecology (Zangmeister et al. 2009). Advanced tracking techniques such as ARGOS and GPS tracking came later to seabirds than other taxonomic groups, due to small size and low weight requirements in order for tags to be feasible for flight, and consequently these have not been deployed extensively on juveniles ( $8.9 \%$ of studies were on juvenile birds; Table 1). Seabirds sizes range from $<30 \mathrm{~g}$ to $>12 \mathrm{~kg}$ and researchers usually restrict tags to 3 to $5 \%$ of the animal's body weight (though further consideration of energetic costs are strongly recommended; Vandenabeele et al. 2012). Most tag designs are still too large for a number of species, even their adult stages. Larger seabirds like procellariiforms (albatrosses and petrels) have juvenile stages large enough to be studied; however only a handful of studies exist. This is likely because juveniles experience high tag loss, and also because researchers are concerned about stressing juvenile animals. Still, seabirds can be reliably found on their breeding colonies, making the tracking logistically simpler than with other taxonomic groups, and also allowing tags to be recovered when birds return to the colony (Burger \& Shaffer 2008).

Three recent reviews of seabird ecology discussed the miniaturization of tags and the increase in remotely sensed oceanographic products as 2 major forces driving the field of seabird ecology (Burger \& Shaffer 2008, Tremblay et al. 2009, Wakefield et al. 2009). GPS tags have been used more extensively for seabirds than other diving animals because much of their at-sea behavior is above the surface. Moreover these tags are small $(<20 \mathrm{~g})$ and can be recovered at breeding colonies (Burger \& Shaffer 2008). Innovative biologging technologies are also being applied, such as heartbeat sensors and beak-mounted magnetic sensors, which are being used to further our understanding of locomotion, foraging costs and ingestion events (Weimerskirch et al. 2000, Wilson et al. 2002); and 'daily tags', initially applied to penguins, that record movement, behavior, energy expenditure and environmental characteristics to understand the full suite of what animals encounter (Wilson et al. 2008).

A seminal study using satellite tracking discovered novel patterns in migration and behavior of the wandering albatross Diomedea exulans, the largest of the seabirds, giving the first metrics for long-range movements of an animal moving sometimes over $900 \mathrm{~km}$ $\mathrm{d}^{-1}$ (Jouventin \& Weimerskirch 1990). As smaller tags have been developed, more seabird species have been tracked, providing a suite of knowledge about migrations, spatial foraging strategies, diving patterns, and variability across years, breeding status, and sexes, and overall revealing the global use of the oceans by seabirds (see Burger \& Shaffer 2008). A number of studies have applied active tags, including GPS, ARGOS and radio-tracking to provide insights into the movements of juvenile penguins, cormorants, albatrosses, boobies, murrelets, and gannets. These studies have shown differences between juvenile and adult movement patterns. A study by Ismar et al. (2010) showed that migratory routes previously unknown for Australasian gannets Morus serrator were undertaken by fledglings of this species. Using a combination of GPS, radio-tracking and stable 
isotopes, Votier et al. (2011) found that northern gannets $M$. bassanus undertake long migrations where they potentially visit non-natal breeding sites. Tracking of pelagic cormorants Phalacrocorax pelagicus using ARGOS transmitters in Alaska revealed that while adults return to foraging grounds within approximately $7 \mathrm{mo}$, juveniles remain on the wintering grounds for over a year, and also tend to remain within localized wintering grounds for longer stretches than adults (Hatch et al. 2011). Several studies on fledgling emperor penguins Aptenodytes forsteri have revealed vastly different movements from those found in adults; fledglings move further, and are not associated with sea ice at all, in contrast with adults who forage and breed in close association with the ice edge year round (Kooyman \& Ponganis 2007, Wienecke et al. 2010). In contrast, a series of studies on Adélie penguins Pygoscelis adeliae showed that fledgling and post-breeding penguins follow similar routes along the ice edge with fledglings having a short 'exploratory' phase at the beginning of their migration (Kooyman et al. 1996, Clarke et al. 2003). One series of studies (Yoda et al. 2004, 2007, Kohno \& Yoda 2011) integrated biologging with hand-rearing of brown booby Sula leucogaster chicks to understand ontogenetic shifts underlying the long post-fledgling care period in this species.

Seabird biologists have been more prolific in applying tracking to conservation and management questions, particularly fishery bycatch, than other groups. For example, a large-scale, multi-investigator study coordinated by BirdLife International (2004) looked at the distribution of procellariiforms obtained from biologging studies and their overlap with pelagic longline fisheries in the southern hemisphere. This study has been used to increase spatial management and bycatch mitigation techniques throughout the region. A more recent study integrated dynamic habitat models from remotely sensed data and tag-derived tracks for albatrosses, analyzing overlap with fishery effort to assess bycatch risk (Zydelis et al. 2011). Several researchers have also applied study results to management issues relevant to juvenile seabirds, providing new strategies for managing seabird populations. In the Southern Ocean, both fledgling and adult breeding movements of southern and northern giant petrels Macronectes giganteus and $M$. halli were examined using ARGOS transmitters, revealing that fledglings move vast distances and overlap more with fisheries than breeding adults, highlighting the need for management strategies that had not been previously considered (Trebilco et al. 2008). Similarly, wandering alba- trosses Diomedea exulans tracked using ARGOS transmitters in the Indian Ocean forage in areas spatially segregated from breeding adults, but show extensive overlap with longline fishing (Weimerskirch et al. 2006). In a related study, it was shown that juveniles use these areas for several years until reaching breeding age, likely returning to these same areas during non-breeding portions of the year (Akesson \& Weimerskirch 2005). These conservation applications of biologging data reap additional benefits over ecological knowledge alone (BirdLife International 2004, Burger \& Shaffer 2008).

Despite these studies, some obvious gaps in our understanding of seabird ecology exist. A recent review by Lewison et al. (2012) identified 6 key elements of seabird ecology in need of additional research, particularly across multiple age classes. Many of these can be directly addressed using satellite tracking, particularly gaps in knowledge of atsea distribution and of environmental drivers determining key foraging grounds. Further study is also required to determine the impacts of fisheries and other anthropogenic stressors in concert with the level of protection provided by marine protected areas. While the studies previously referred to provide a preliminary understanding of changes in the movements of juveniles, there is still insufficient understanding of ecology across age classes to comprehensively manage seabird populations.

\section{DISCUSSION AND CONCLUSIONS}

Tagging studies have the unique ability to identify individual-level variability in behavioral data (e.g. Schaefer et al. 2007), previously unidentified habitat (Mate et al. 2007), and ecological linkages at multiple life history stages. To date, tagging efforts have focused on the mature life stages, i.e. on individuals that can carry larger tags and have lower mortality, which has resulted in a gap of studies on less-accessible juvenile and larval life stages. In the literature, we found that marine fish and turtle studies had far greater percentages of tagging studies focused on juvenile life stages (>20\%) compared to seabirds and mammals $(<10 \%)$ (Table 1$)$. Differential life history strategies may in part be responsible for this difference in emphasis. Intra-annual life history stages have different physiological requirements, which may result in different critical habitat and exposure to risks (e.g. breeding versus migration versus foraging; Kenney et al. 2001, Kappes et al. 2010). The literature searches did not examine species-specific patterns in 
tagging studies, but previous review papers have shown unequal effort across species that is perhaps due to differences in ease of capture for tagging or access to research funding (e.g. Godley et al. 2007).

In order to better understand the biology of marine organisms, one of the next steps will be to increase the diversity of tagging effort, across life history stages, sexes, and species, particularly to inform conservation and management (Maxwell et al. 2011). The majority of large marine taxa are either species of conservation concern, or are critical components of the ecosystem in which they reside. A number of tracking studies have been used to inform management and conservation, particularly to site marine protected areas, reduce bycatch, and to employ other spatial management measures (Grémillet et al. 2000, Chilvers et al. 2005, Boersma et al. 2007, Howell et al. 2008, Shillinger et al. 2008, Zydelis et al. 2011, Hart et al. 2012, Scott et al. in press). It is critical to have a holistic understanding of the distribution of a population in order to effectively protect the entire population, and to not employ management strategies that might have unintended consequences (e.g. shifting of fishing effort to areas of unknown high abundance; Baum et al. 2003).

We identified the following 4 research themes in the introduction, (1) population demography and recruit mortality, (2) critical juvenile habitat and threat overlap, (3) dispersal and population connectivity, and (4) foraging ecology. Table 2 assesses the relative research effort among the themes by taxonomic group. These themes were also identified as research priorities for both seabirds and turtles in recent reviews (Hamann et al. 2010, Lewison et al. 2012). We found that tag-based studies for all 4 groups adequately adressed population structure, mortality, and habitat of juveniles, while questions of dispersal, population connectivity and structure, and foraging ecology were less explored using tag-based methods (Table 2). Furthermore, we found very few tag-based studies that explicitly examined the overlap between juvenile habitat and anthropogenic threats, so we excluded that category from our analyses. Similar to the taxonomic breakdown in Table 1, marine mammals (especially cetaceans and sirenians) and seabirds had the most gaps in juvenile tagbased ecological studies, although sea turtles were not far behind (Table 2). More advanced tags were most useful in answering questions in the categories 'habitat' and 'foraging ecology', although this pattern was not identical across taxonomic groups. Moreover, we found examples of the use of passive tags combined with molecular techniques to answer more complicated ecological questions (e.g. Friesen et al. 2007).

In mark-recapture studies, passive tags are still one of the primary tools used to answer questions about mortality and recruitment, i.e. spaghetti and PIT tags in juvenile fish (Pine et al. 2003), bands for pinnipeds, seabirds, and turtles (Schaub \& Pradel 2004, Robinson et al. 2010), and photo-ID catalogs for marine mammals (Hammond 2002). Alternative approaches such as archival tagging paired with genetic techniques have been used to delineate Atlantic bluefin tuna Thunnus thynnus stocks, measure migration rates, and estimate mortality (Taylor et al. 2011), building upon the classic mark-recapture technique. Acoustic or archival tags also can be used to measure mortality in a number of these species, but it can be difficult to differentiate between tag failure and mortality (Townsend et al. 2006). Studies of seabirds, turtles and mammals were less likely to use radio or acoustic tags to assess mortality rates compared to fish, perhaps in part due to central place foragers being more easily assessed upon return to land. The effort devoted to assessing dispersal and connectivity was greatest in fish, at least in part due to the longer history of fish tagging studies. Due to the wide-ranging nature of and difficulty in tag attachment for many top predators, molecular and genetic techniques have been more widely used to examine their dispersal and population connectivity (e.g. Thorrold et al. 2002, Amaral et al. 2012). Acoustic and radio tags have been used in concert with portable receiving stations and visual observation to both calculate use metrics for habitat and measure foraging behavior for both turtles and fish species (Cooke et al. 2004, Ropert-Coudert \& Wilson 2005, Myers \& Hays 2006). Measurements of energetic costs and foraging behavior have been made possible with advanced technologies such as magnetic sensors to identify foraging events in seabirds (Cooke et al. 2004), internal temperature and heart rate loggers in fish and pinnipeds (Andrews 1998, Block 2005), and accelerometer tags in cetaceans (Goldbogen et al. 2011). These advanced techniques have been infrequently applied to juveniles because of tag-size limitations, but bird researchers have been grappling with this issue for some time due to the lower weight of most seabirds, and the other groups could learn from their efforts (e.g. Mansfield et al. 2012, this Theme Section).

Data gaps are common in marine science, as funding opportunities and research topics can be ephemeral. Technological challenges have limited our ability to use tags to study juvenile life stages, but these challenges are being overcome as tags contin- 
ually become lighter, have increased battery life, and more sensors on-board. Cell phone tags use offthe-shelf products to increase data accessibility and transmission using existing cellular networks (McConnell et al. 2004). Other off-the-shelf products, such as GPS tags originally designed for human recreational activities, are a cost-effective means of tracking seabirds (M. Conners and S. Shaffer, pers. comm.). Oceanographic sensors can turn animals into measurement platforms providing ocean data (Hooker \& Boyd 2003, Block 2005). Also, tag miniaturization efforts have allowed novel tagging studies including the tagging of younger life history stages, such as with juvenile loggerhead turtles. Mansfield et al. (2012) have, for the first time, shown novel migration pathways in neonate marine turtles, with some individuals tracking the Gulf Stream and others heading east into the North Atlantic Gyre.

Significant effort has been made to understand the ethical implications of tagging, both in considering the effects on individuals and populations and in defining the goals of tagging studies. There has been much debate in the field of tagging about the negative effects on fitness of specific tag types across taxonomic groups. In seabirds, penguin banding led to decreased breeding success in poor resource years leading to potential spurious interpretations (Saraux et al. 2011). For marine mammals, hot branding for pinnipeds and implantable satellite tags may not cause long-term physiological harm (Merrick et al. 1996, Mate et al. 2007, McMahon et al. 2008), but behavioral effects of such tagging methods have not been well documented (Walker et al. 2010). For turtle species, harnessbased satellite tags used largely on leatherback turtles have recently been identified as increasing drag and chafing and alternative attachment methods are now available (Jones et al. 2011, Witt et al. 2011). Mrosovsky (1983) termed the interest in continuing to deploy tags without a clear scientific question or without a given end goal in mind the 'tagging reflex'. Researchers should determine whether enough is known about a species or population before tagging studies begin, otherwise tagging without specific goals may have deleterious population effects that could outweigh the potential knowledge gained. Because scientific questions and ethical considerations drive tag deployments, especially with regard to smaller animals and early life stages, it is important to document and minimize the effect of tagging and to ensure that deployments are only used when necessary to further our knowledge and conservation of the study species.
One of the weaknesses of active tag data is that only a small number of animals tend to be tracked, which generally represents a small proportion of the population. Findings can be scaled up by including complementary forensic methods such as stable isotope tracking (Zbinden et al. 2011). Another approach is represented by interspecific, broad-scale tagging efforts such as the Tagging of Pacific Predators project, which has created a rare and valuable dataset (Block et al. 2011). The Pacific Ocean Salmon Tracking project has adopted a similar broad-scale approach, linking acoustic tagging efforts on the west coast with a series of arrays, thereby allowing nearshore detections of many acoustically tagged individuals as part of the Census of Marine Life (Welch et al. 2002). Synthetic collaboration across multiple datasets can be equally informative, such as BirdLife's Procellariform Database that has aided meta-analyses and informed management objectives on seabirds throughout the world (BirdLife International 2004). Data repositories such as OBIS-SEAMAP (Halpin et al. 2006) or the Satellite Tracking Analysis Tool (Coyne \& Godley 2005) serve an equally valuable role in amalgamating data, assessing data gaps and allowing meta-analyses of multiple tagging datasets. These large databases and synthetic research programs provide needed baselines for marine populations that are difficult to study, and cover sufficiently broad scales to allow the examination of long-term processes such as climatic change. With increased collaboration and ongoing diversification of methods and approaches, we can use marking and tagging to continue to answer ecological questions and to adaptively manage marine ecosystems.

\section{LITERATURE CITED}

Ainley DG, Sydeman WJ, Hatch SA, Wilson UW (1994) Seabird population trends along the west coast of North America: causes and the extent of regional concordance. Stud Avian Biol 15:119-133

> Akesson S, Weimerskirch H (2005) Albatross long-distance navigation: comparing adults and juveniles. J Navig 58: 365-373

Amaral AR, Beheregaray LB, Bilgmann K, Boutov D and others (2012) Seascape genetics of a globally distributed, highly mobile marine mammal: the short-beaked common dolphin (genus Delphinus). PLoS ONE 7:e31482

Andrews RD (1998) Remotely releasable instruments for monitoring the foraging behaviour of pinnipeds. Mar Ecol Prog Ser 175:289-294

Andrews RD, Pitman RL, Balance LT (2008) Satellite tracking reveals distinct movement patterns for Type B and Type C killer whales in the southern Ross Sea, Antarctica. Polar Biol 31:1461-1468 
Arnold G, Dewar H (2001) Electronic tags in marine fisheries research:a 30-year perspective. In: Sibert J, Nielsen J (eds) Methods and technologies in fish biology and fisheries, Vol 1. Kluwer Academic Press, Dordrecht, p 7-64

Bailey H, Benson SR, Shillinger GL, Bograd SJ and others (2012) Leatherback turtle movement patterns. Bull Ecol Soc Am 93:165-169

Balazs G (1999) Factors to consider in the tagging of sea turtles. In: Eckert K, Bjorndal K, Abreu-Grobois F, Donnelly $M$ (eds) Research and management techniques for the conservation of sea turtles. IUCN/SSC Marine Turtle Specialist Group Publication No. 4, Washington, DC

Balon EK (1986) Types of feeding in the ontogeny of fishes and the life-history model. Environ Biol Fishes 16:11-24

Barbour AB, Adams AJ (2012) Biologging to examine multiple life stages of an estuarine-dependent fish. Mar Ecol Prog Ser 457:241-250

> Baum JK, Myers RA, Kehler DG, Worm B, Harley SJ, Doherty PA (2003) Collapse and conservation of shark populations in the Northwest Atlantic. Science 299: 389-392

Bayliff WH (1988) Integrity of schools of skipjack tuna, Katsuwonus pelamis, in the eastern Pacific Ocean, as determined from tagging data. Fish Bull 86:631-643

> Beck MW, Heck KLJ, Able KW, Childers DL and others (2001) The identification, conservation, and management of estuarine and marine nurseries for fish and invertebrates. Bioscience 51:633-641

Benson SR, Eguchi T, Foley D, Forney KA and others (2011) Large-scale movements and high-use areas of western Pacific leatherback turtles, Dermochelys coriacea. Ecosphere 2:1-27. doi:10.1890/ES11-00053.1

> Best PB, Payne R, Rowntree V, Palazzo JT, Both MDC (1993) Long-range movements of South Atlantic right whales Eubalaena australis. Mar Mamm Sci 9:227-234

Bestley S, Patterson TA, Hindell MA, Gunn JS (2008) Feeding ecology of wild migratory tunas revealed by archival tag records of visceral warming. J Anim Ecol 77: 1223-1233

BirdLife International (2004). Tracking ocean wanderers: the global distribution of albatrosses and petrels. Results from the Global Procellariiform Tracking Workshop, 1-5 September, 2003, Gordon's Bay, South Africa. BirdLife International, Cambridge

Bjørge A, Bekkby T, Bryant EB (2002) Summer home range and habitat selection of harbor seal (Phoca vitulina) pups. Mar Mamm Sci 18:438-454

Bjorndal KA, Bolten AB, Chaloupka MY (2000) Green turtle somatic growth model: evidence for density-dependence. Ecol Appl 10:269-282

- Block BA (2005) Physiological ecology in the 21st century: advancements in biologging science. Integr Comp Biol 45:305-320

Block BA, Dewar H, Farwell C, Prince ED (1998) A new satellite technology for tracking the movements of Atlantic bluefin tuna. Proc Natl Acad Sci USA 95: 9384-9389

> Block BA, Dewar H, Blackwell S, Williams T (2001) Migratory movements, depth preferences, and thermal biology of Atlantic bluefin tuna. Science 293:1310-1314

> Block BA, Jonsen ID, Jorgensen SJ, Winship AJ and others (2011) Tracking apex marine predator movements in a dynamic ocean. Nature 475:86-90

- Boehme L, Thorpe SE, Biuw M, Fedak M, Meredith MP (2008) Monitoring Drake Passage with elephant seals: frontal structures and snapshots of transport. Limnol Oceanogr 53:2350-2360

Boersma PD, Rebstock GA, Stokes DL, Majluf P (2007) Oceans apart: conservation models for two temperate penguin species shaped by the marine environment. Mar Ecol Prog Ser 335:217-225

> Bograd SJ, Block BA, Costa DP, Godley BJ (2010) Biologging technologies: new tools for conservation. Endang Species Res 10:1-7

> Bonfil R (2005) Transoceanic migration, spatial dynamics, and population linkages of white sharks. Science 310: 100-103

Bonter DN, Bridge ES (2011) Applications of radio frequency identification (RFID) in ornithological research: a review. J Field Ornithol 82:1-10

Bowen BW, Kamezaki N, Limpus CJ (1994) Global phylogeography of the loggerhad turtle (Caretta caretta) as indicated by mitochondrial DNA haplotypes. Evolution 48:1820-1828

$>$ Bradshaw CJA (2005) Survival of the fittest technologyproblems estimating marine turtle mortality. Mar Ecol Prog Ser 287:261-262

> Bradshaw CJA, Barker RJ, Davis LS (2000) Modeling tag loss in New Zealand fur seal pups. J Agric Biol Environ Stat 5:475-485

Brady DC, Targett TE, Tuzzolino DM (2009) Behavioral responses of juvenile weakfish (Cynoscion regalis) to diel-cycling hypoxia: swimming speed, angular correlation, expected displacement, and effects of hypoxia acclimation. Can J Fish Aquat Sci 66:415-424

Breed GA, Bowen WD, Leonard ML (2011) Development of foraging strategies with age in a long-lived marine predator. Mar Ecol Prog Ser 431:267-279

Brooks L, Harvey J, Nichols W (2009) Tidal movements of East Pacific green turtle Chelonia mydas at a foraging area in Baja California Sur, México. Mar Ecol Prog Ser 386:263-274

> Burger AE, Shaffer SA (2008) Perspectives in ornithology: application of tracking and data-logging technology in research and conservation of seabirds. Auk 125:253-264

Burns JM (1999) The development of diving behaviour in juvenile Weddell seals: pushing physiological limits in order to survive. Can J Zool 77:737-747

Calambokidis J, Steiger GH, Straley JM, Herman LM and others (2001) Movements and population structure of humpback whales in the North Pacific. Mar Mamm Sci 17:769-794

Calambokidis J, Schorr GS, Steiger GH, Francis J and others (2007) Insights into the underwater diving, feeding, and calling behavior of blue whales from a suction-cupattached video-imaging tag (Crittercam). Mar Technol Soc J 41:19-29

> Campagna C, Piola AR, Rosa Marin M, Lewis M, Zajaczkovski U, Fernandez T (2007) Deep divers in shallow seas: southern elephant seals on the Patagonian shelf. Deep-Sea Res I 54:1792-1814

Carr A (1967) So excellent a fishe. Natural History Press, Garden City, NY

Castro-Santos T, Haro A, Walk S (1996) A passive integrated transponder (PIT) tag system for monitoring fishways. Fish Res 28:253-261

Chaloupka MY, Limpus CJ (2005) Estimates of sex- and ageclass-specific survival probabilities for a southern Great Barrier Reef green sea turtle population. Mar Biol 146: 1251-1261 
Chaloupka M, Bjorndal KA, Balazs GH, Bolten AB and others (2008) Encouraging outlook for recovery of a once severely exploited marine megaherbivore. Glob Ecol Biogeogr 17:297-304

> Chilvers BL, Wilkinson IS, Duignan PJ, Gemmell NJ (2005) Identifying the distribution of summer foraging areas for lactating New Zealand sea lions Phocarctos hookeri. Mar Ecol Prog Ser 304:235-247

> Clarke J, Kerry K, Fowler C, Lawless R, Eberhard S, Murphy $\mathrm{R}$ (2003) Post-fledging and winter migration of Adélie penguins Pygoscelis adeliae in the Mawson region of East Antarctica. Mar Ecol Prog Ser 248:267-278

> Clark TD, Taylor BD, Seymour RS, Ellis D, Buchanan J, Fitzgibbon QP, Frappell PB (2008) Moving with the beat: heart rate and visceral temperature of free-swimming and feeding bluefin tuna. Proc Biol Sci 275:2841-2850

> Cooke SJ, Hinch SG, Wikelski M, Andrews RD, Kuchel LJ, Wolcott TG, Butler PJ (2004) Biotelemetry: a mechanistic approach to ecology. Trends Ecol Evol 19:334-343

Cordes LS, Duck CD, Mackey BL, Hall AJ, Thompson PM (2011) Long-term patterns in harbour seal site-use and the consequences for managing protected areas. Anim Conserv 14:430-438

Corkeron PJ, Connor RC (1999) Why do baleen whales migrate? Mar Mamm Sci 15:1228-1245

Costa DP, Robinson PW, Arnould JPY, Harrison AL and others (2010a) Accuracy of ARGOS locations of pinnipeds at-sea estimated using Fastloc GPS. PLoS ONE 5:e8677

Costa DP, Huckstadt LA, Crocker DE, McDonald BI, Goebel ME, Fedak MA (2010b) Approaches to studying climatic change and its role on the habitat selection of Antarctic pinnipeds. Integr Comp Biol 50:1018-1030

Cowen RK, Sponaugle S (2009) Larval dispersal and marine population connectivity. Annu Rev Mar Sci 1:443-466

Coyne MS, Godley BJ (2005) Satellite Tracking and Analysis Tool (STAT): an integrated system for archiving, analyzing and mapping animal tracking data. Mar Ecol Prog Ser 301:1-7

Croll DA, Tershy BR, Hewitt RP, Demer DA and others (1998) An integrated approach to the foraging ecology of marine birds and mammals. Deep-Sea Res II 45: 1353-1371

Cunjak RA, Roussel JM, Gray M, Dietrich J, Cartwright D, Munkittrick K, Jardine T (2005) Using stable isotope analysis with telemetry or mark-recapture data to identify fish movement and foraging. Oecologia 144:636-646

> Cury PM, Boyd IL, Bonhommeau S, Anker-Nilssen T and others (2011) Global seabird response to forage fish depletion-one-third for the birds. Science 334: 1703-1706

> Dryden J, Grech A, Moloney J, Hamann M (2008) Rezoning of the Great Barrier Reef World Heritage Area: does it afford greater protection for marine turtles? Wildl Res 35: 477-485

$>$ Eckert SA (2002) Swim speed and movement patterns of gravid leatherback sea turtles (Dermochelys coriacea) at St Croix, US Virgin Islands. J Exp Biol 205:3689-3697

Eckert SA, Eckert KL, Ponganis P, Kooyman G (1989) Diving and foraging behavior of leatherback sea turtles (Dermochelys coriacea). Can J Zool 67:2834-2840

Elliott JM (1989) Mechanisms responsible for population regulation in young migratory trout, Salmo trutta. I. The critical time for survival. J Anim Ecol 58:987-1001

Everhart WH, Eipper AW, Youngs WD (1975) Principles of fishery science. Cornell University Press, Ithaca, NY

Fedak MA, Lovell P, McConnell BJ, Hunter C (2002) Overcoming the constraints of long range radio telemetry from animals: getting more useful data from smaller packages. Integr Comp Biol 42:1-10

Field IC, Bradshaw CJA, Burton HR, Sumner MD, Hindell MA (2005) Resource partitioning through oceanic segregation of foraging juvenile southern elephant seals (Mirounga leonina). Oecologia 142:127-135

> Flamm RO, Weigle BL, Wright E, Ross M, Aglietti S (2005) Estimation of manatee (Trichechus manatus latirostris) places and movement corridors using telemetry data. Ecol App 15:1415-1426

Fowler SL, Costa DP, Arnould JPY (2007) Ontogeny of movements and foraging ranges in the Australian sea lion. Mar Mamm Sci 23:598-614

Friesen VL, Burg TM, McCoy KD (2007) Mechanisms of population differentiation in seabirds. Mol Ecol 16: 1765-1785

Gillanders BM, Able KW, Brown JA, Eggleston DB, Sheridan PF (2003) Evidence of connectivity between juvenile and adult habitats for mobile marine fauna: an important component of nurseries. Mar Ecol Prog Ser 247:281-295

Godley BJ, Blumenthal JM, Broderick AC, Coyne MS, Godfrey $\mathrm{MH}$, Hawkes LA, Witt MJ (2007) Satellite tracking of sea turtles: where have we been and where do we go next? Endang Species Res 4:3-22

Godley BJ, Barbosa C, Bruford M, Broderick AC and others (2010) Unravelling the migratory connectivity in marine turtles using multiple methods. J Appl Ecol 47:769-778

Goldbogen JA, Calambodkis J, Oleson E, Potvin J, Pyenson ND, Schorr G, Shadwick RE (2011) Mechanics, hydrodynamics and energetics of blue whale lunge feeding: efficiency dependence on krill density. J Exp Biol 214: 131-146

> Gómez Laich A, Wilson RP, Quintana F, Shepard ELC (2009) Identification of imperial cormorant Phalacrocorax atriceps behaviour using accelerometers. Endang Species Res 10:29-37

Grémillet D, Wilson RP, Wanless S, Chater T (2000) Blackbrowed albatrosses, international fisheries and the Patagonian Shelf. Mar Ecol Prog Ser 195:269-280

Guttridge TL, Gruber SH, Krause J, Sims DW (2010) Novel acoustic technology for studying free-ranging shark social behaviour by recording individuals' interactions. PLoS ONE 5:e9324

- Gyuris E (1994) The rate of predation by fishes on hatchlings of the green turtle. Coral Reefs 13:137

> Halpin PN, Read AJ, Best BD, Hyrenbach KD and others (2006) OBIS-SEAMAP: developing a biogeographic research data commons for the ecological studies of marine mammals, seabirds, and sea turtles. Mar Ecol Prog Ser 316:239-246

> Hamann M, Godfrey MH, Seminoff JA, Arthur K and others (2010) Global research priorities for sea turtles: informing management and conservation in the 21 st century. Endang Species Res 11:245-269

Hammerschlag N, Gallagher AJ, Lazarre DM (2011) A review of shark satellite tagging studies. J Exp Mar Biol Ecol 398:1-8

Hammond PS (2002) The assessment of marine mammal population size and status. In: Evans PGH, Raga JA (eds) Marine mammals: biology and conservation. Kluwer Academic, London, p 269-291 
Hanuise N, Bost CA, Huin W, Auber A, Halsey LG, Handrich Y (2010) Measuring foraging activity in a deep-diving bird: comparing wiggles, oesophageal temperatures and beak-opening angles as proxies of feeding. J Exp Biol 213:3874-3880

Hart KM, Hyrenbach KD (2009) Satellite telemetry of marine megavertebrates: the coming of age of an experimental science. Endang Species Res 10:9-20

Hart KM, Lamont MM, Fujisaki I, Tucker AD, Carthy RR (2012) Common coastal foraging areas for loggerheads in the Gulf of Mexico: opportunities for marine conservation. Biol Conserv 145:185-194

Hatch SA, Gill VA, Mulcahy DM (2011) Migration and wintering sites of pelagic cormorants determined by satellite telemetry. J Field Ornithol 82:269-278

> Hays GC, Broderick AC, Glen F, Godley BJ, Nichols WJ (2001) The movements and submergence behaviour of male green turtles at Ascension Island. Mar Biol 139: 395-399

> Hazel J (2009) Evaluation of fast-acquisition GPS in stationary tests and fine-scale tracking of green turtles. J Exp Mar Biol Ecol 374:58-68

- Hazel J, Lawler IR, Hamann M (2009) Diving at the shallow end: green turtle behavior in near-shore foraging habitat. J Exp Mar Biol Ecol 371:84-92

> Hazen EL, Friedlaender AS, Thompson M, Ware C, Weinrich M, Halpin P, Wiley D (2009) Fine-scale prey aggregations and foraging ecology of humpback whales Megaptera novaeangliae. Mar Ecol Prog Ser 395:75-89

> Heithaus MR, Marshall GJ, Buhleier BM, Dill LM (2001) Employing Crittercam to study habitat use and behavior of large sharks. Mar Ecol Prog Ser 209:307-310

- Hodgson AJ, Marsh H (2007) Response of dugongs to boat traffic: the risk of disturbance and displacement. J Exp Mar Biol Ecol 340:50-61

> Holland KN, Meyer CG, Dagorn LC (2009) Inter-animal telemetry: results from first deployment of acoustic 'business card' tags. Endang Species Res 10:287-293

> Hooker SK, Boyd IL (2003) Salinity sensors on seals: use of marine predators to carry CTD data loggers. Deep-Sea Res I 50:927-939

> Hooker S, Gerber LR (2004) Potential importance of megafauna: marine reserves as a tool for ecosystem-based management? Bioscience 54:27-41

- Horning M, Hill RD (2005) Designing an archival satellite transmitter for life-long deployments on oceanic vertebrates: the life history transmitter. IEEE J Oceanic Eng 30:807-817

> Horning M, Mellish JAE (2012) Predation on an upper trophic marine predator, the Steller sea lion: evaluating high juvenile mortality in a density dependent conceptual framework. PLoS ONE 7:e30173

Houde E (1997) Patterns and trends in larval stage growth and mortality of teleost fish. J Fish Biol 51:52-83

> Howell EA, Kobayashi DR, Parker DM, Balazs GH, Polovina JJ (2008) TurtleWatch: a tool to aid in the bycatch reduction of loggerhead turtles Caretta caretta in the Hawaiibased pelagic longline fishery. Endang Species Res 5: 267-278

> Hughes GR, Luschi P, Mencacci R, Papi F (1998) The 7000 $\mathrm{km}$ oceanic journey of a leatherback turtle tracked by satellite. J Exp Mar Biol Ecol 229:209-217

Humphries NE, Queiroz N, Dyer JRM, Pade NG and others (2010) Environmental context explains Lévy and Brown- ian movement patterns of marine predators. Nature 465: 1066-1069

- Ismar SMH, Hunter C, Lay K, Ward-Smith T, Wilson PR, Hauber ME (2010) A virgin flight across the Tasman Sea? Satellite tracking of post-fledging movement in the Australasian gannet Morus serrator. J Ornithol 151:755-759

Jefferson TA, Leatherwood S, Webber MA (1993) Marine mammals of the world. Species Identification Guide, FAO, Rome

> Jeglinski JWE, Werner C, Robinson PW, Costa DP, Trillmich F (2012) Age, body mass and environmental variation shape the foraging ontogeny of Galapagos sea lions. Mar Ecol Prog Ser 453:279-296

Johnson MP, Tyack PL (2003) A digital acoustic recording tag for measuring the response of wild marine mammals to sound. IEEE J Oceanic Eng 28:3-12

Jones TT, Bostrom B, Carey M, Imlach B and others (2011) Determining transmitter drag and best-practice attachment procedures for sea turtle biotelemetry. NOAA-TMNMFS-SWFSC-480

Josse E, Bach P, Dagorn L (1998) Simultaneous observations of tuna movements and their prey by sonic tracking and acoustic surveys. Hydrobiologia 371-372:61-69

Jouventin P, Weimerskirch H (1990) Satellite tracking of wandering albatrosses. Nature 343:746-748

Kappes MA, Shaffer SA, Tremblay Y, Foley DG and others (2010) Hawaiian albatrosses track interannual variability of marine habitats in the North Pacific. Prog Oceanogr 86:246-260

Kenney R, Mayo C, Winn H (2001) Migration and foraging strategies at varying spatial scales in western North Atlantic right whales: a review of hypotheses. J Cetacean Res Manag (Spec) 2:251-260

Kingsley MCS, Gosselin S, Sleno GA (2001) Movements and dive behaviour of belugas in Northern Quebec. Arctic 54:262-275

Kipling C, Lecren E (1984) Mark-recapture experiments on fish in Windermere, 1943-1982. J Fish Biol 24:395-414

Kohno H, Yoda K (2011) The development of activity ranges in juvenile brown boobies Sula leucogaster. Ibis 153: 611-615

Kooyman GL (2004) Genesis and evolution of bio-logging devices: 1963-2002. Mem Natl Inst Polar Res (Spec) 58: $15-22$

> Kooyman GL, Ponganis PJ (2007) The initial journey of juvenile emperor penguins. Aquat Conserv Mar Freshw Ecosys 17:S37-S43

> Kooyman GL, Kooyman TG, Horning M, Kooyman CA (1996) Penguin dispersal after fledging. Nature 383:397

Lagerquist BA, Mate BR, Ortega-Ortiz JG, Winsor M, Urbán-Ramirez J (2008) Migratory movements and surfacing rates of humpback whales (Megaptera novaeangliae) satellite tagged at Socorro Island, Mexico. Mar Mamm Sci 24:815-830

- Le Boeuf BJ, Morris PA, Blackwell SB, Crocker DE, Costa DP (1996) Diving behavior of juvenile northern elephant seals. Can J Zool 74:1632-1644

> Lewison R, Oro D, Godley BJ, Underhill L and others (2012) Research priorities for seabirds: improving conservation and management in the 21st century. Endang Species Res 17:93-121

Limpus CJ (1992) Estimation of tag loss in marine turtle research. Wildl Res 19:457-469

Limpus CJ, Limpus DJ (2001) The loggerhead turtle, Caretta caretta, in Queensland: breeding migrations and fidelity 
to a warm temperate feeding area. Chelonian Conserv Biol 4:142-153

Limpus CJ, Limpus DJ (2003). Biology of the loggerhead turtle in western South Pacific Ocean foraging areas. In: Bolten A, Witherington B (eds) Loggerhead sea turtles. Smithsonian Institution Press, Washington, DC, p 93-113

Limpus CJ, Miller JD, Parmenter CJ, Reimer D, McLahan N, Webb R (1992) Migration of green (Chelonia mydas) and loggerhead (Caretta caretta) turtles to and from eastern Australian rookeries. Wildl Res 19:347-358

Limpus CJ, Miller JD, Parmenter CJ (2003) The green turtle, Chelonia mydas, population of Raine Island and the northern Great Barrier Reef: 1843-2001. Mem Queensl Mus 49:349-440

Loughlin TR, Sterling JT, Merrick ML, Sease JL, York AE (2003) Diving behavior of immature Steller sea lions (Eumetopias jubatus). Fish Bull 101:566-582

Lowry LF, Burkanov VN, Frost KJ, Simpkins MA and others (2000) Habitat use and habitat selection by spotted seals (Phoca largha) in the Bering Sea. Can J Zool 78: 1959-1971

Mansfield KL, Wyneken J, Rittschoff D, Walsh M, Lim CW, Richards PM (2012) Satellite tag attachment methods for tracking neonate sea turtles. Mar Ecol Prog Ser 457: 181-192

Marsh H, O'Shea TJ, Reynolds JE (2011) Ecology and conservation of Sirenia: dugongs and manatees. Cambridge University Press, Cambridge

Mate BR, Nieukirk SL, Kraus SD (1997) Satellite-monitored movements of the northern right whale. J Wildl Manag 61:1393-1405

- Mate BR, Krutzikowsky GK, Winsor M (2000) Satellitemonitored movements of radio-tagged bowhead whales in the Beaufort and Chukchi seas during the late-summer feeding season and fall migration. Can J Zool 78: 1168-1181

> Mate B, Mesecar R, Lagerquist B (2007) The evolution of satellite-monitored radio tags for large whales: one laboratory's experience. Deep-Sea Res II 54:224-247

> Maxwell SM, Breed GA, Nickel BA, Makanga-Bahouna J and others (2011) Using satellite tracking to optimize protection of long-lived marine species: olive ridley sea turtle conservation in Central Africa. PLoS ONE 6: e19905

> McClellan CM, Read AJ (2009) Confronting the gauntlet: understanding incidental capture of green turtles through fine-scale movement studies. Endang Species Res 10:165-179

McConnell BJ, Fedak MA, Lovell P, Hammond PS (1999) Movements and foraging areas of grey seals in the North Sea. J Appl Ecol 36:573-590

> McConnell BJ, Bryant E, Hunter C, Lovell P, Hall A (2004) Phoning home-a new GSM mobile phone telemetry system to collect mark-recapture data. Mar Mamm Sci 20:274-283

McConnell B, Fedak M, Hooker S, Patterson T (2010) Telemetry. In: Boyd IL, Bowen WD, Iverson SJ (eds) Marine mammal ecology and conservation: a handbook of techniques. Oxford University Press, Oxford, p 222-242

> McMahon CR, Burton HR, Bester MN (2003) A demographic comparison of two southern elephant seal populations. J Anim Ecol 72:61-74

McMahon CR, Burton HR, van Den Hoff J, Woods R, Bradshaw CJA (2006) Assessing hot-iron and cryo-branding for permanently marking southern elephant seals. J Wildl Manag 70:1484-1489

McMahon CR, Field IC, Bradshaw CJA, White GC, Hindell MA (2008) Tracking and data-logging devices attached to elephant seals do not affect individual mass gain or survival. J Exp Mar Biol Ecol 360:71-77

Melnychuk MC, Walters CJ, Christensen V, Bothwell ML, Welch DW (2012) Effects of solar ultraviolet radiation exposure on early ocean survival and fry-to-smolt growth of juvenile salmon. Mar Ecol Prog Ser 457: 251-264

Merrick RL, Loughlin TR, Calkins DG (1996) Hot branding: a technique for long-term marking of pinnipeds. NOAATM-NMFS-AFSC-68

Mrosovsky N (1983) Conserving sea turtles. British Herpetological Society, London

Musick JA, Limpus CJ (1997) Habitat utilization and migration in juvenile sea turtles. In: Lutz P, Musick JA (eds) Biology of sea turtles. CRC Press, Boca Raton, FL, p 137-163.

Myers AE, Hays GC (2006) Do leatherback turtles Dermochelys coriacea forage during the breeding season? A combination of data-logging devices provide new insights. Mar Ecol Prog Ser 322:259-267

Naito Y (2004) New steps in biologging science. Mem Natl Inst Polar Res SI58:50-57

Nielsen A, Bigelow KA, Musyl MK, Sibert JR (2006) Improving light-based geolocation by including sea surface temperature. Fish Oceanogr 15:314-325

Okuyama J, Kawabata Y, Naito Y, Arai N, Kobayashi M (2009) Monitoring beak movements with an acceleration datalogger: a useful technique for assessing the feeding and breathing behaviors of sea turtles. Endang Species Res 10:39-45

> Oosthuizen WC, Bester MN, Tosh CA, Guinet C, Besson D, de Bruyn PJN (2011) Dispersal and dispersion of southern elephant seals in the Kerguelen Province, Southern Ocean. Antarct Sci 23:567-577

Page B, McKenzie J, Sumner MD, Coyne M, Goldsworthy SD (2006) Spatial separation of foraging habitats among New Zealand fur seals. Mar Ecol Prog Ser 323:263-279

Palumbi SR, Gaines SD, Leslie H, Warner RR (2003) New wave: high-tech tools to help marine reserve research. Front Ecol Environ 1:73-79

> Phalan B, Phillips RA, Silk JRD, Afanasyev V and others (2007) Foraging behaviour of four albatross species by night and day. Mar Ecol Prog Ser 340:271-286

> Phillips RA, Silk JRD, Croxall JP, Afanasyev V, Briggs DR (2004) Accuracy of geolocation estimates for flying seabirds. Mar Ecol Prog Ser 266:265-272

Pine W, Pollock K, Hightower J, Kwak T, Rice J (2003) A review of tagging methods for estimating fish population size and components of mortality. Fisheries (Bethesda) 28:10-23

> Pistorius PA, Bester MN, Kirkman SP, Boveng PL (2000) Evaluation of age- and sex-dependent rates of tag loss in southern elephant seals. J Wildl Manag 64:373-380

Pollock KH (1991) Modeling capture, recapture, and removal statistics for estimation of demographic parameters for fish and wildlife populations: past, present, and future. J Am Stat Assoc 86:225-238

Pollock KH, Marsh H, Bailey LL, Farnsworth GL, Simons TL, Alldredge MW (2004) Separating components of detection probability in abundance estimation: an overview with diverse examples. In: Thompson WL (ed) Sampling 
rare and elusive species: concepts, designs and techniques for estimating population parameters. Island Press, Washington DC, p 43-58

Rasmussen K, Palacios DM, Calambokidis J, Saborío MT and others (2007) Southern Hemisphere humpback whales wintering off Central America: insights from water temperature into the longest mammalian migration. Biol Lett 3:302-305

Raum-Suryan KL, Rehberg MJ, Pendleton GW, Pitcher KW, Gelatt TS (2004) Development of dispersal, movement patterns, and haul-out use by pup and juvenile Steller sea lions (Eumetopias jubatus) in Alaska. Mar Mamm Sci 20:823-850

Reich KJ, Bjorndal KA, Bolten AB (2007) The 'lost years' of green turtles: using stable isotopes to study cryptic lifestages. Biol Lett 3:712-714

Robinson WD, Bowlin MS, Bisson I, Shamoun-Baranes J and others (2010) Integrating concepts and technologies to advance the study of bird migration. Front Ecol Environ 8:354-361

Ropert-Coudert Y, Wilson RP (2005) Trends and perspectives in animal-attached remote-sensing. Front Ecol Environ 3:437-444

Rowat D, Meekan M, Engelhardt U, Pardigon B, Vely M (2007) Aggregations of juvenile whale sharks (Rhincodon typus) in the Gulf of Tadjoura, Djibouti. Environ Biol Fishes 80:465-472

> Royer F, Fromentin JM, Gaspar P (2005) A state-space model to derive bluefin tuna movement and habitat from archival tags. Oikos 109:473-484

Rutz C, Hays GC (2009) New frontiers in biologging science. Biol Lett 5:289-292

Salmon M, Hamann M, Wyneken J (2010) The development of early diving behavior by juvenile flatback sea turtles (Natator depressus). Chelonian Conserv Biol 9:8-17

- Santidrián Tomillo P, Saba VS, Piedra R, Paladino FV, Spotila JR (2008) Effects of illegal harvest of eggs on the population decline of leatherback turtles in Las Baulas Marine National Park, Costa Rica. Conserv Biol 22: 1216-1224

Santidrián Tomillo P, Paladino FV, Suss JS, Spotila JR (2010) Predation of leatherback turtle hatchlings during the crawl to the water. Chelonian Conserv Biol 9:18-25

Saraux C, Le Bohec C, Durant JM, Viblanc VA and others (2011) Reliability of flipper-banded penguins as indicators of climate change. Nature 469:203-206

Schaefer KM, Fuller DW, Block BA (2007) Movements, behavior, and habitat utilization of yellowfin tuna (Thunnus albacares) in the northeastern Pacific Ocean, ascertained through archival tag data. Mar Biol 152:503-525

Schaub M, Pradel R (2004) Assessing the relative importance of different sources of mortality from recoveries of marked animals. Ecology 85:930-938

Schofield G, Hobson VJ, Fossette S, Lilley MKS, Katselis KA, Hays GC (2010) Fidelity to foraging sites, consistency of migration routes and habitat modulation of home range by sea turtles. Divers Distrib 16:840-853

Scott R, Hodgson DJ, Witt MJ, Coyne MS and others (in press) Global analysis of satellite tracking data shows that adult green turtles are significantly aggregated in Marine Protected Areas. Glob Ecol Biogeogr

Shepard ELC, Wilson RP, Quintana F, Gómez Laich A and others (2008) Identification of animal movement patterns using tri-axial accelerometry. Endang Species Res 10: $47-60$
Sheppard JK, Preen AR, Marsh H, Lawler IR, Whiting SD, Jones RE (2006) Movement heterogeneity of dugongs, Dugong dugon (Muller), over large spatial scales. J Exp Mar Biol Ecol 334:64-83

Shillinger GL, Palacios DM, Bailey H, Bograd SJ and others (2008) Persistent leatherback turtle migrations present opportunities for conservation. PLoS Biol 6:e171

Shillinger GL, Swithenbank AM, Bograd SJ, Bailey H and others (2010) Identification of high-use internesting habitats for eastern Pacific leatherback turtles: role of the environment and implications for conservation. Endang Species Res 10:215-232

Shillinger GL, Swithenbank AM, Bailey H, Bograd SJ and others (2011) Vertical and horizontal habitat preferences of post-nesting leatherback turtles in the South Pacific Ocean. Mar Ecol Prog Ser 422:275-289

Shillinger GL, Di Lorenzo E, Luo H, Bograd S, Hazen E, Bailey H, Spotila JR (2012) On the dispersal of leatherback hatchlings from Mesoamerican nesting beaches. Proc Biol Sci 279:2391-2395

Sibert JR, Nielsen JL (eds) (2001) Electronic tagging and tracking in marine fisheries. Kluwer Academic Publishers, Dordrecht

Sims DW (2010) Tracking and analysis techniques for understanding free-ranging shark movements and behaviour. In: Carrier JC, Musick JA, Heithaus MR (eds) Biology of sharks and their relatives, Vol 2. CRC Press, Boca Raton, FL, p 341-392

Sims DW, Queiroz N, Humphries NE, Lima FP, Hays GC (2009) Long-term GPS tracking of ocean sunfish Mola mola offers a new direction in fish monitoring. PLoS ONE 4:e7351

Stimpert AK, Wiley DN, Au WWL, Johnson MP, Arsenault R (2007) 'Megaclicks': acoustic click trains and buzzes produced during night-time foraging of humpback whales (Megaptera novaeangliae). Biol Lett 3:467-470

Taquet C, Taquet M, Dempster T, Soria M, Ciccione S, Roos D, Dagorn L (2006) Foraging of the green sea turtle Chelonia mydas on seagrass beds at Mayotte Island (Indian Ocean) determined by acoustic transmitters. Mar Ecol Prog Ser 306:295-302

Taylor NG, McAllister MK, Lawson GL, Carruthers T, Block BA (2011) Atlantic bluefin tuna: a novel multistock spatial model for assessing population biomass. PLoS ONE 6:e27693

> Teo SLH, Boustany A, Blackwell SB, Walli A, Weng KC, Block BA (2004) Validation of geo-location estimates based on light level and sea surface temperature from electronic tags. Mar Ecol Prog Ser 283:81-98

- Thorrold SR (2001) Natal homing in a marine fish metapopulation. Science 291:297-299

Thorrold SR, Jones G, Hellberg ME, Burton RS and others (2002) Quantifying larval retention and connectivity in marine populations with artificial and natural markers. Bull Mar Sci 70:291-308

> Townsend RL, Skalski JR, Dillingham P, Steig TW (2006) Correcting bias in survival estimation resulting from tag failure in acoustic and radiotelemetry studies. J Agric Biol Environ Stat 11:183-196

> Trebilco R, Gales R, Baker GB, Terauds A, Sumner MD (2008) At sea movement of Macquarie Island giant petrels: relationships with marine protected areas and regional fisheries management organisations. Biol Conserv 141:2942-2958

Tremblay Y, Bertrand S, Henry RW, Kappes MA, Costa DP, 
Shaffer SA (2009) Analytical approaches to investigating seabird-environment interactions: a review. Mar Ecol Prog Ser 391:153-163

Trites AW, Donnelly CP (2003) The decline of Steller sea lions Eumetopias jubatus in Alaska: a review of the nutritional stress hypothesis. Mammal Rev 33:3-28

Tucker AD (2010) Nest site fidelity and clutch frequency of loggerhead turtles are better elucidated by satellite telemetry than by nocturnal tagging efforts: implications for stock estimation. J Exp Mar Biol Ecol 383: 48-55

Tucker AD, FitzSimmons NN, Limpus CJ (1995) Conservation implications of internesting habitat use by loggerhead turtles Caretta caretta in Woongarra Marine Park, Queensland, Australia. Pac Conserv Biol 2: 157-156

Tyson RB, Friedlaender AS, Ware C, Stimpert AK, Nowacek DP (2012) Synchronous mother and calf foraging behaviour in humpback whales Megaptera novaeangliae: insights from multi-sensor suction cup tags. Mar Ecol Prog Ser 457:209-220

> Vandenabeele SP, Shepard EL, Grogan A, Wilson RP (2012) When three percent may not be three percent; deviceequipped seabirds experience variable flight constraints. Mar Biol 159:1-14

Voegeli FA, Smale MJ, Webber DM, Andrade Y, O'Dor RK (2001) Ultrasonic telemetry, tracking and automated monitoring technology for sharks. Environ Biol Fishes 60: 267-282

> Votier SC, Grecian WJ, Patrick S, Newton J (2011) Intercolony movements, at-sea behaviour and foraging in an immature seabird: results from GPS-PPT tracking, radiotracking and stable isotope analysis. Mar Biol 158: 355-362

> Wakefield ED, Phillips RA, Matthiopoulos J (2009) Quantifying habitat use and preferences of pelagic seabirds using individual movement data: a review. Mar Ecol Prog Ser 391:165-182

Walker KA, Mellish JE, Weary DM (2010) Behavioural responses of juvenile Steller sea lions to hot-iron branding. Appl Anim Behav Sci 122:58-62

Walker KA, Trites AW, Haulena M, Weary DM (2012) A review of the effects of different marking and tagging techniques on marine mammals. Wildl Res 39:15-30

> Ware CR, Arsenault R, Plumlee M, Wiley D (2006) Visualizing the underwater behavior of humpback whales. IEEE Comput Graph Appl 26:14-18

Weber SB, Blount JD, Godley BJ, Witt MJ, Broderick AC (2011) Rate of egg maturation in marine turtles exhibits 'universal temperature dependence'. J Anim Ecol 80: 1034-1041

> Weimerskirch H, Brothers N, Jouventin P (1997) Population dynamics of wandering albatross Diomedea exulans and Amsterdam albatross D. amsterdamensis in the Indian Ocean and their relationships with long-line fisheries: conservation implications. Biol Conserv 79: $257-270$

Weimerskirch H, Guionnet T, Martin J, Shaffer SA, Costa DP (2000) Fast and fuel-efficient? Optimal use of wind by flying albatrosses. Proc Biol Sci 267:1869-1874

Weimerskirch H, Akesson S, Pinaud D (2006) Postnatal dispersal of wandering albatrosses Diomedea exulans: implications for the conservation of the species. J Avian Biol 37:23-28
Welch D, Boehlert G, Ward B (2002) POST-the Pacific Ocean salmon tracking project. Oceanol Acta 25: 243-253

Weng KC, Stokesbury MJW, Boustany AM, Seitz AC, Teo SLH, Miller SK, Block BA (2009) Habitat and behavior of yellowfin tuna Thunnus albacares in the Gulf of Mexico determined using pop-up satellite archival tags. J Fish Biol 74:1434-1449

White W, Beamish R (1972) A simple fish tag suitable for long-term marking experiments. J Fish Res Board Can 29:339-341

> Whiting SD, Miller JD (1998) Short term foraging ranges of adult green turtles (Chelonia mydas). J Herpetol 32: 330-337

> Wibbels T, Owens DW, Limpus CJ, Reed PC, Amoss MS (1990) Seasonal changes in serum gonadal steroids associated with migration, mating, and nesting in the loggerhead sea turtle (Caretta caretta). Gen Comp Endocrinol 79:154-164

- Wienecke B, Raymond B, Robertson G (2010) Maiden journey of fledgling emperor penguins from the Mawson Coast, East Antarctica. Mar Ecol Prog Ser 410:269-282

> Wilson B, Hammond PS, Thompson PM (1999) Estimating size and assessing status of a coastal bottlenose dolphin population. Ecol Appl 9:288-300

Wilson RP, Steinfurth A, Ropert-Coudert Y, Kato A, Kurita M (2002) Lip-reading in remote subjects: an attempt to quantify and separate ingestion, breathing and vocalisation in free-living animals using penguins as a model. Mar Biol 140:17-27

Wilson RP, Shepard ELC, Liebsch N (2008) Prying into the intimate details of animal lives: use of a daily diary on animals. Endang Species Res 4:123-137

Witt MJ, Broderick AC, Coyne MS, Formia A and others (2008) Satellite tracking highlights difficulties in the design of effective protected areas for critically endangered leatherback turtles Dermochelys coriacea during the inter-nesting period. Oryx 42:296-300

Witt MJ, Åkesson S, Broderick AC, Coyne MS and others (2010a) Assessing accuracy and utility of satellite-tracking data using Argos-linked Fastloc-GPS. Anim Behav 80:571-581

Witt MJ, McGowan A, Blumenthal JM, Broderick AC and others (2010b) Inferring vertical and horizontal movements of juvenile marine turtles from time-depth recorders. Aquat Biol 8:169-177

Witt MJ, Godley BJ, Broderick AC, Coyne MS (2011) Tracking leatherback turtles from the world's largest rookery: assessing threats across the South Atlantic. Proc Biol Sci 278:2338-2347

> Witteveen B, Worthy G, Wynne K, Roth J (2009) Population structure of North Pacific humpback whales on their feeding grounds revealed by stable carbon and nitrogen isotope ratios. Mar Ecol Prog Ser 379:299-310

> Yoda K, Kohno H, Naito Y (2004) Development of flight performance in the brown booby. Proc Biol Sci 271: S240-S242

> Yoda K, Kohno H, Naito Y (2007) Ontogeny of plunge diving behaviour in brown boobies: application of a data logging technique to hand-raised seabirds. Deep-Sea Res II 54:321-329

Zangmeister JL, Haussmann MF, Cerchiara J, Mauck RA (2009) Incubation failure and nest abandonment by Leach's storm-petrels detected using pit tags and temperature loggers. J Field Ornithol 80:373-379 
Zbinden JA, Aebischer A, Margaritoulis D, Arlettaz R (2007) Insights into the management of sea turtle internesting area through satellite telemetry. Biol Conserv 137: $157-162$

Zbinden JA, Bearhop S, Bradshaw P, Gill B, Margaritoulis D, Newton J, Godley BJ (2011) Migratory dichotomy and

Submitted: February 20, 2011; Accepted: June 1, 2012 associated phenotypic variation in marine turtles revealed by satellite tracking and stable isotope analysis. Mar Ecol Prog Ser 421:291-302

Zydelis R, Lewison RL, Shaffer SA, Moore JE and others (2011) Dynamic habitat models: using telemetry data to project fisheries bycatch. Proc Biol Sci 278:3191-3200

Proofs received from author(s): June 17, 2012 